\title{
WATER-LEVEL DATA FOR THE ALBUQUERQUE BASIN, CENTRAL NEW MEXICO, PERIOD OF RECORD THROUGH 1997
}

By Dale R. Rankin

\section{U.S. GEOLOGICAL SURVEY}

Open-File Report 98-408

Prepared in cooperation with the CITY OF ALBUQUERQUE 


\title{
U.S. DEPARTMENT OF THE INTERIOR BRUCE BABBITT, Secretary
}

\author{
U.S. GEOLOGICAL SURVEY
}

Thomas J. Casadevall, Acting Director

The use of firm, trade, and brand names in this report is for identification purposes only and does not constitute endorsement by the U.S. Geological Survey.

For additional information write to:

District Chief

U.S. Geological Survey

Water Resources Division

4501 Indian School Road NE, Suite 200

Albuquerque, NM 87110-3929
Copies of this report can be purchased from:

U.S. Geological Survey

Branch of Information Services

Box 25286

Denver, CO 80225-0286 


\section{CONTENTS}

Abstract.
Introduction
$\quad$ Well-numbering system
Methods
Water-level and other data
References cited

\section{FIGURES}

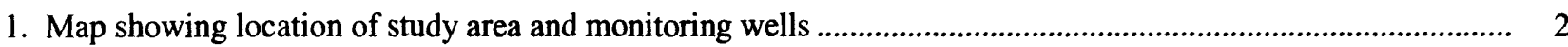

2. Map showing location of monitoring wells in the Albuquerque area ................................................................. 3

3. Diagram showing well-numbering system in New Mexico.............................................................................. 4

4. Hydrographs showing water-level data for selected wells and piezometers in the Albuquerque Basin:

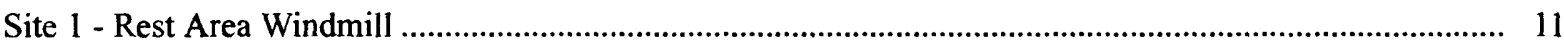

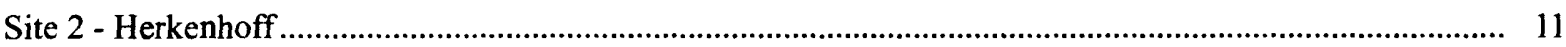

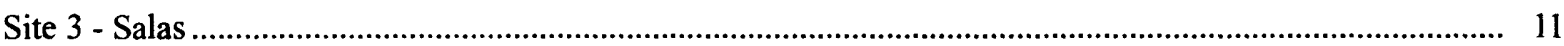

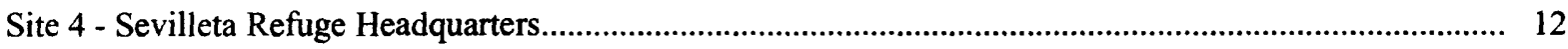

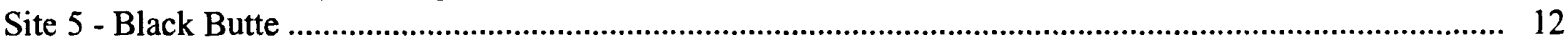

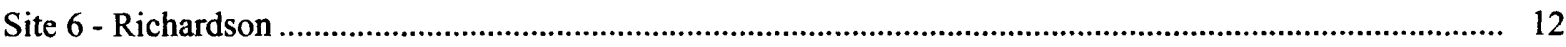

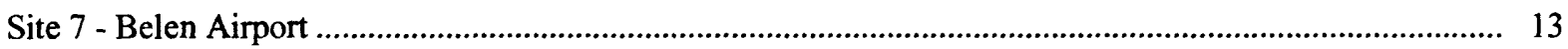

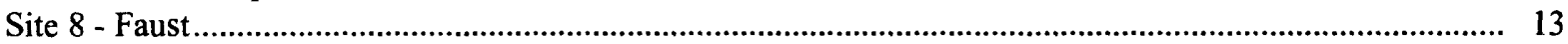

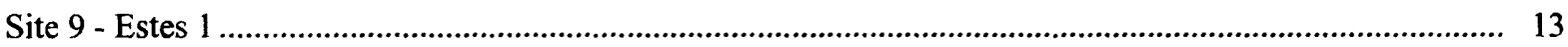

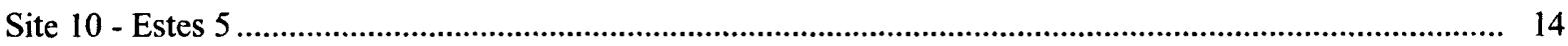

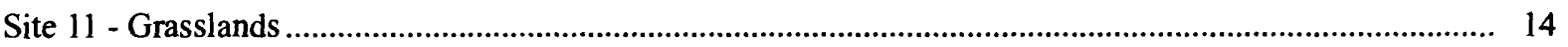

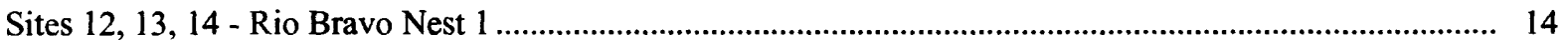

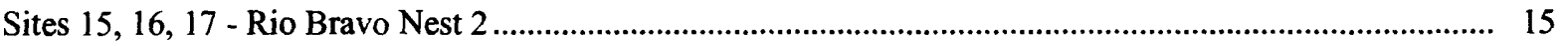

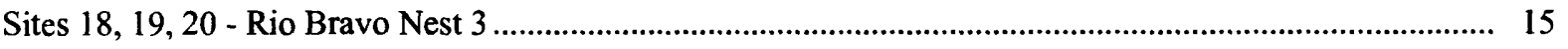

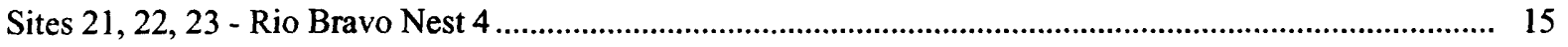

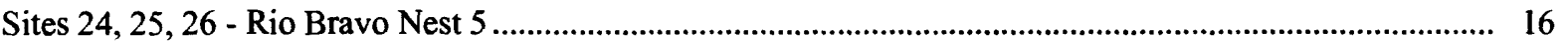

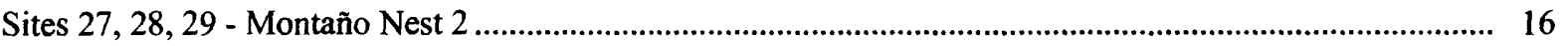

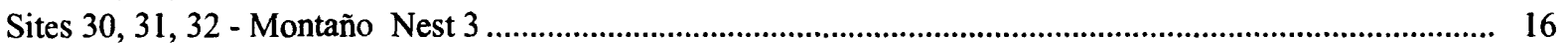

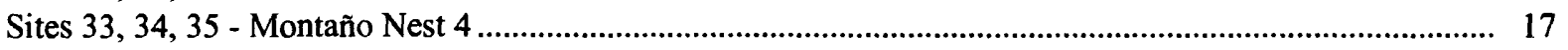

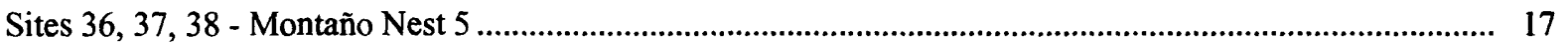

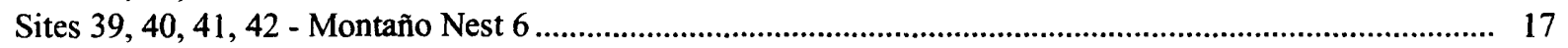

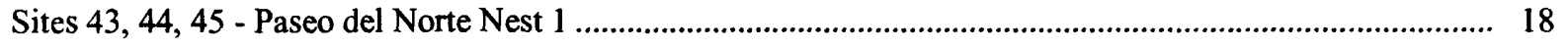

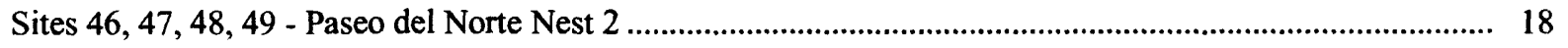

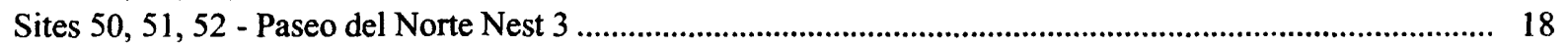

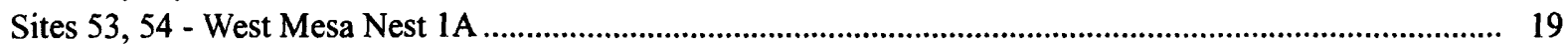

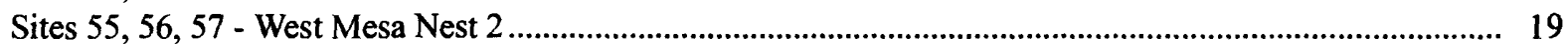

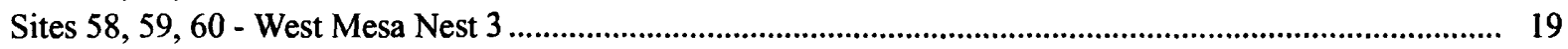

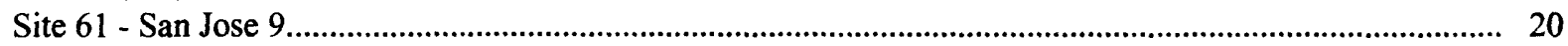

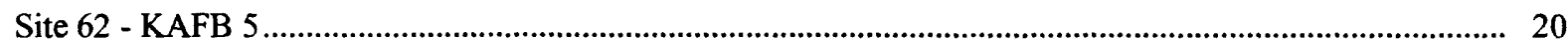

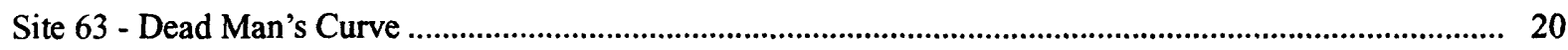

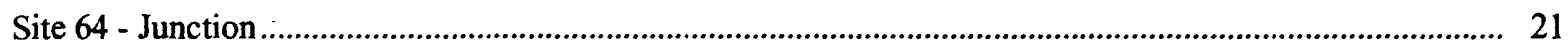


Site 65 - Home Oil

Site 66 - Granite Hill.

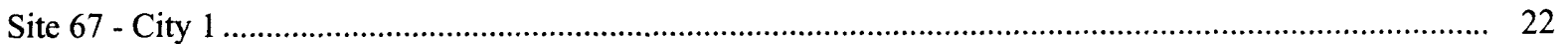

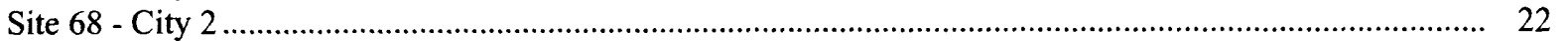

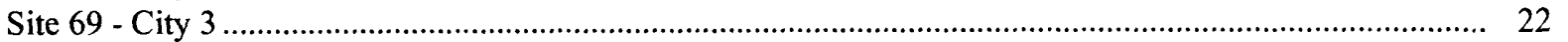

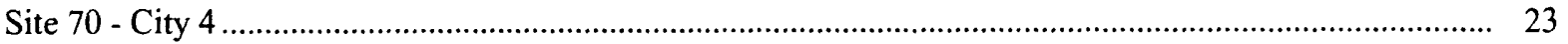

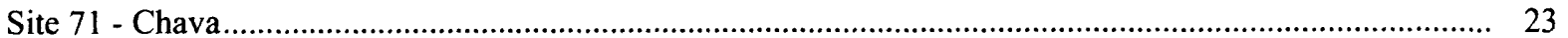

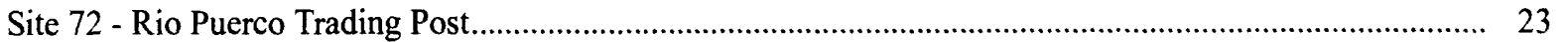

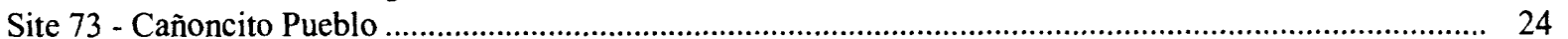

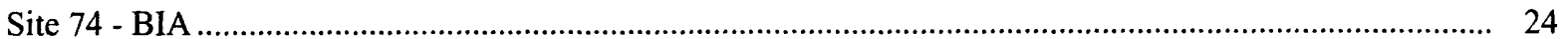

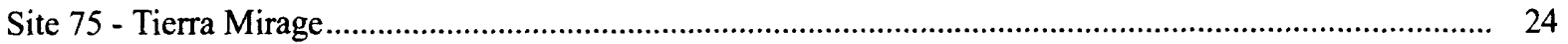

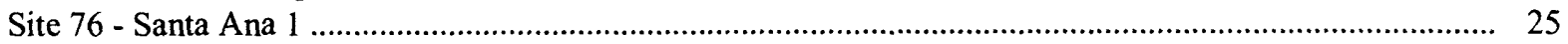

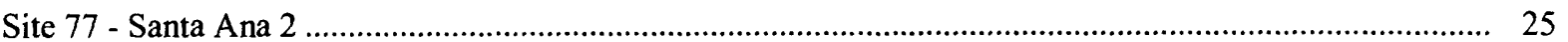

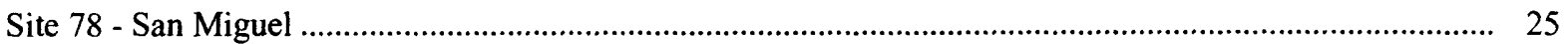

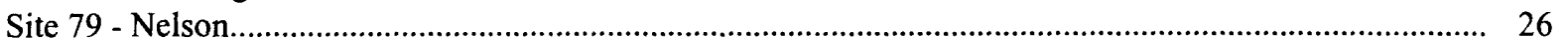

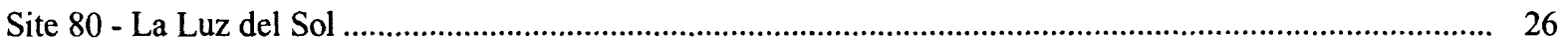

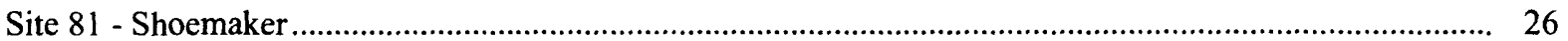

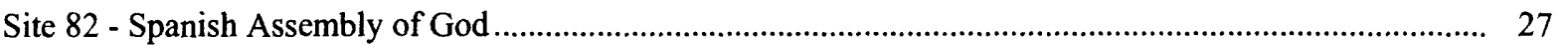

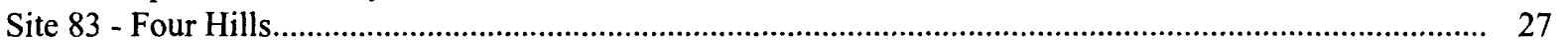

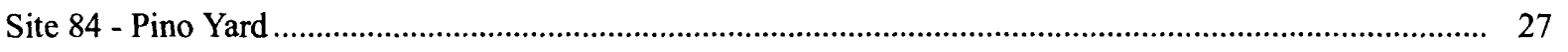

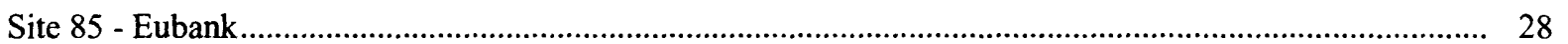

\section{TABLES}

1. Well and piezometer data for the Albuquerque Basin, New Mexico.

CONVERSION FACTORS AND VERTICAL DATUM

\begin{tabular}{|c|c|c|}
\hline Multiply & By & To obtain \\
\hline foot & 0.3048 & meter \\
\hline mile & 1.609 & kilometer \\
\hline acre & 0.4047 & hectare \\
\hline
\end{tabular}




\title{
WATER-LEVEL DATA FOR THE ALBUQUERQUE BASIN, CENTRAL NEW MEXICO, PERIOD OF RECORD THROUGH 1997
}

\author{
By Dale R. Rankin
}

\section{Abstract}

The Albuquerque Basin, located in central New Mexico, is about 100 miles long and 25 to 40 miles wide. The basin is defined as the extent of Cenozoic deposits that encompass the structural Rio Grande Rift within the basin. Drinking-water supplies throughout the Albuquerque Basin are obtained solely from ground-water resources. The population of the basin grew from 419,000 in 1980 to 563,600 in 1990, a 34-percent increase, and resulted in increases in water demand and groundwater pumpage. Between April 1982 and September 1983, a network of wells was established to monitor changes in ground-water levels throughout the Albuquerque Basin. Waterlevel data were collected at 85 wells and piezometers for the period of record through 1997. Water-level data currently (1997) are collected annually at sites 11 and 53-57; semiannually at sites $1-10,75$, and 82 ; quarterly at sites $12-52,64-$ $74,76,77,79-81,84$, and 85 ; monthly at sites 58 60,78 , and 83 ; and hourly at sites 61-63.

\section{INTRODUCTION}

The Albuquerque Basin is located in central New Mexico and is about 100 miles long and 25 to 40 miles wide (fig. 1). The basin is defined as the extent of Cenozoic deposits that encompass the structural Rio Grande Rift within the basin (Thorn and others, 1993). The study area extends from Bernalillo south to San Acacia and from Tijeras Canyon west to near the intersection of Interstate 40 and the Bernalillo/Cibola County line. Parts of Sandoval, Bernalillo, Valencia, and Socorro Counties are located within the study area. The only perennial stream is the southward-flowing Rio Grande, which approximately bisects the basin.
The Albuquerque metropolitan area includes a population of 502,100 (U.S. Department of Commerce, 1991) (fig. 2). Although the majority of people are concentrated within the Albuquerque city limits, the basinwide population grew from 419,000 in 1980 to 563,600 in 1990 (U.S. Bureau of the Census, 1980, 1991), an increase of 34 percent. The demand for ground water has likewise increased because drinkingwater supplies throughout the Albuquerque Basin are obtained solely from ground-water resources (Kues, 1987).

This report, prepared in cooperation with the City of Albuquerque, presents information about a water-level monitoring network, cooperatively operated by the City of Albuquerque (City) and the U.S. Geological Survey (USGS), in the Albuquerque Basin, central New Mexico (Wilkins, 1986; Anderholm and Bullard, 1987; and Kues, 1987). The data are from the period of record through 1997.

\section{Well-Numbering System}

The system of numbering wells in New Mexico is based on the common subdivision of public lands into sections (fig. 3). The well number, in addition to designating the well, locates its position to the nearest 10 -acre tract in the land network. This number is divided into four segments. The first segment denotes the township north of the New Mexico base line, the second denotes the range east of the New Mexico principal meridian, and the third denotes the section. The fourth segment of the number, which consists of three digits, denotes the 160-, 40-, and 10-acre tracts, respectively, in which the well is situated. For this purpose, the section is divided into four quarters, numbered $1,2,3$, and 4 , in the normal reading order, for the northwest, northeast, southwest, and southeast quarters. The first digit of the fourth segment gives the quarter section, which is a tract of 160 acres. Similarly, the quarter section is divided into four 40 -acre tracts numbered in the same manner, and the second digit 


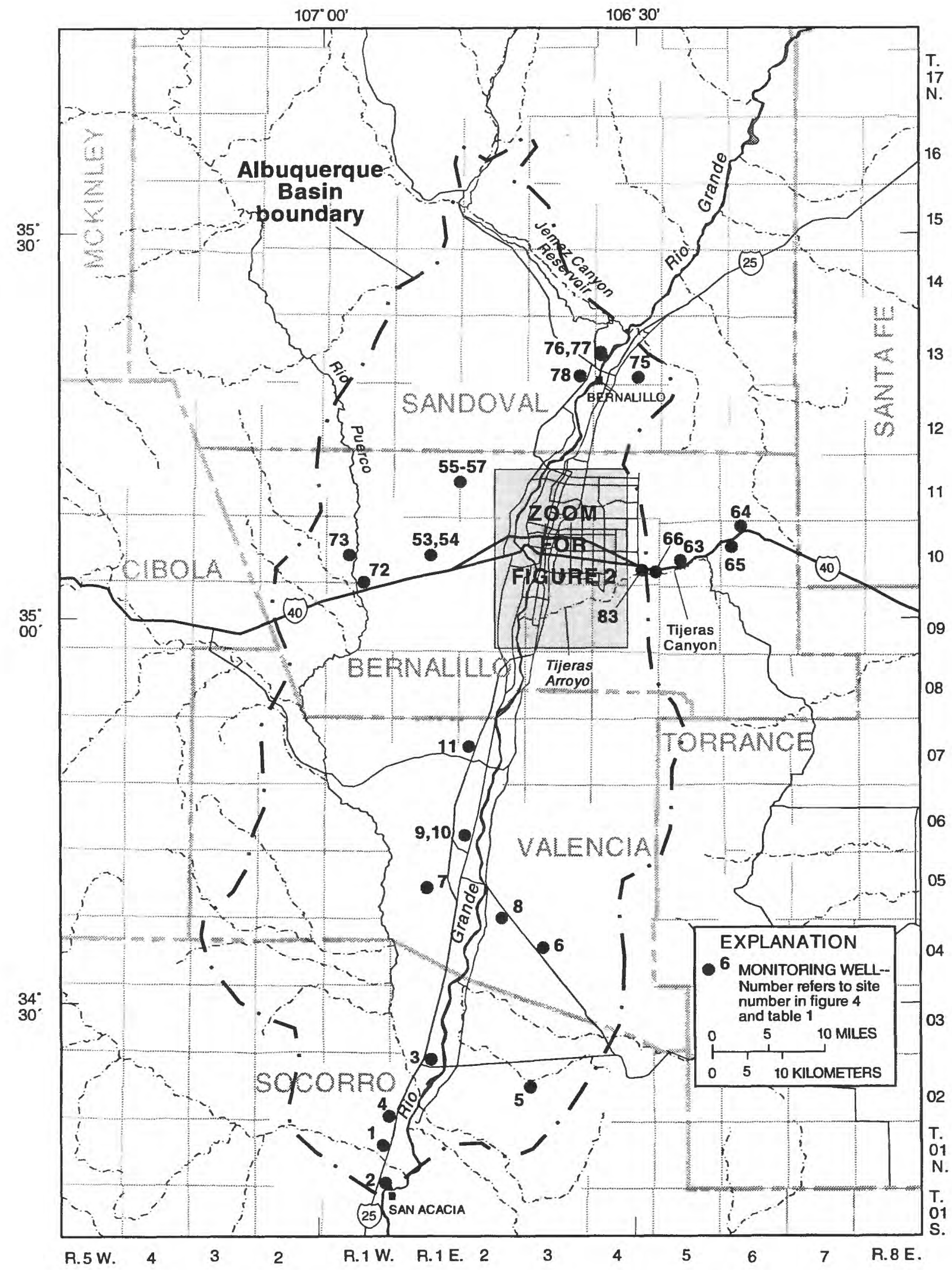

Figure 1. -- Location of study area and monitoring wells. 


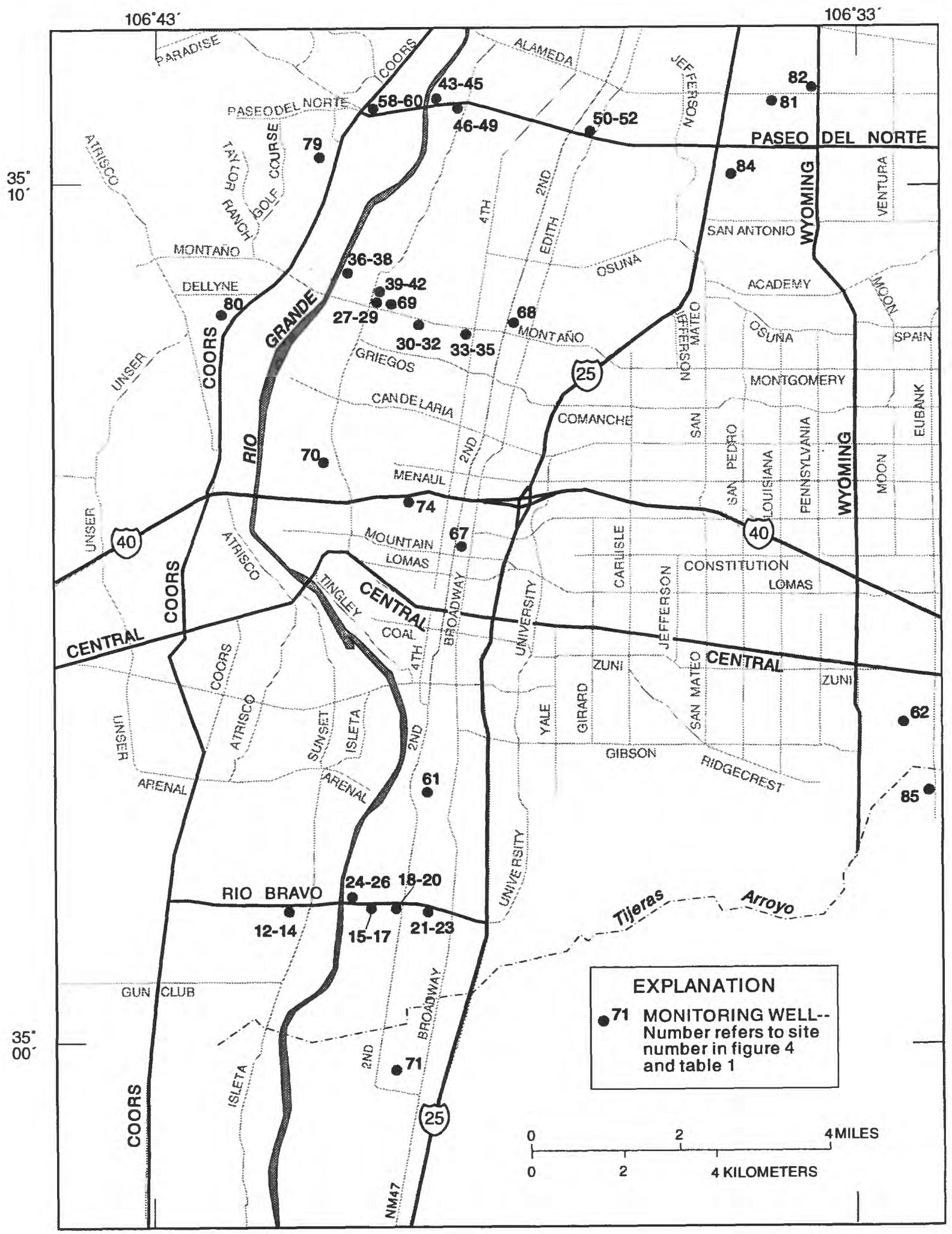

Figure 2.--Location of monitoring wells in the Albuquerque area. 
denotes the 40 -acre tract. Finally, the 40 -acre tract is divided into four 10-acre tracts, and the third digit denotes the 10-acre tract. For example, well 09N.03E.07.131A is in the NW $1 / 4$ of the SW1/4 of the NW 1/4 of section 7, T. 09 N., R. 03 E. (fig. 3). Letters $\mathrm{A}, \mathrm{B}, \mathrm{C}$, and so on are added to the last segment of the well number to designate the second, third, fourth, and succeeding wells in the same 10 -acre tract.

\section{Methods}

Water-level data were collected by U.S. Geological Survey personnel. Currently (as of October 1, 1997), water-level data are collected annually at sites 11 and 53-57; semiannually at sites 110,75 , and 82 ; quarterly at sites $12-52,64-74,76,77$, $79-81,84$, and 85; monthly at sites 58-60, 78, and 83; and hourly at sites 61-63. Electric and steel tapes are used to collect water-level data at sites 1-60 and 64-85. Fischer-Porter recorders are used to collect water-level data at sites 61-63. Recorded data (sites 61-63) are incomplete because of recorder malfunction or temporary removal of the recorder for geophysical logging or sampling.
WATER-LEVEL AND OTHER DATA

Well and piezometer data are listed in table 1; these data include site number and identifier, local identifier, owner, other identifier, total depth, and screened interval. Hydrographs of water-level data for the period of record through 1997 are shown in figure 4 . The data presented in the hydrographs include depth to water and hydraulic head.

Water-level data through September 30, 1995, are presented in three previous USGS Open-File Reports. The first such report (Kues, 1987) includes water-level data collected through September 30, 1985; the second report (Rankin, 1994) includes water-level data collected from October 1, 1985, through September 30, 1990; the third and most recent report (Rankin, 1996) includes water-level data collected from the period of record through September 30, 1995.

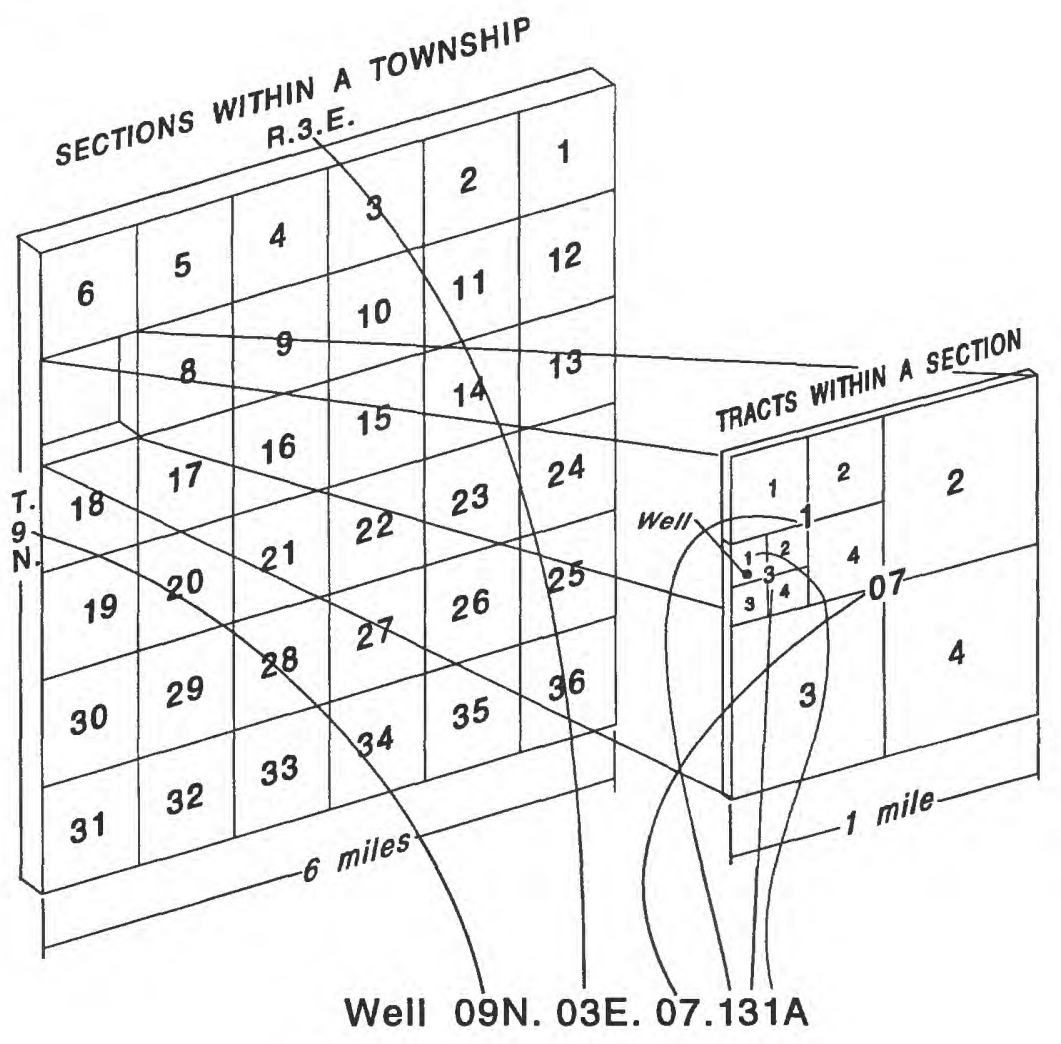

Figure 3.--Well-numbering system in New Mexico. 


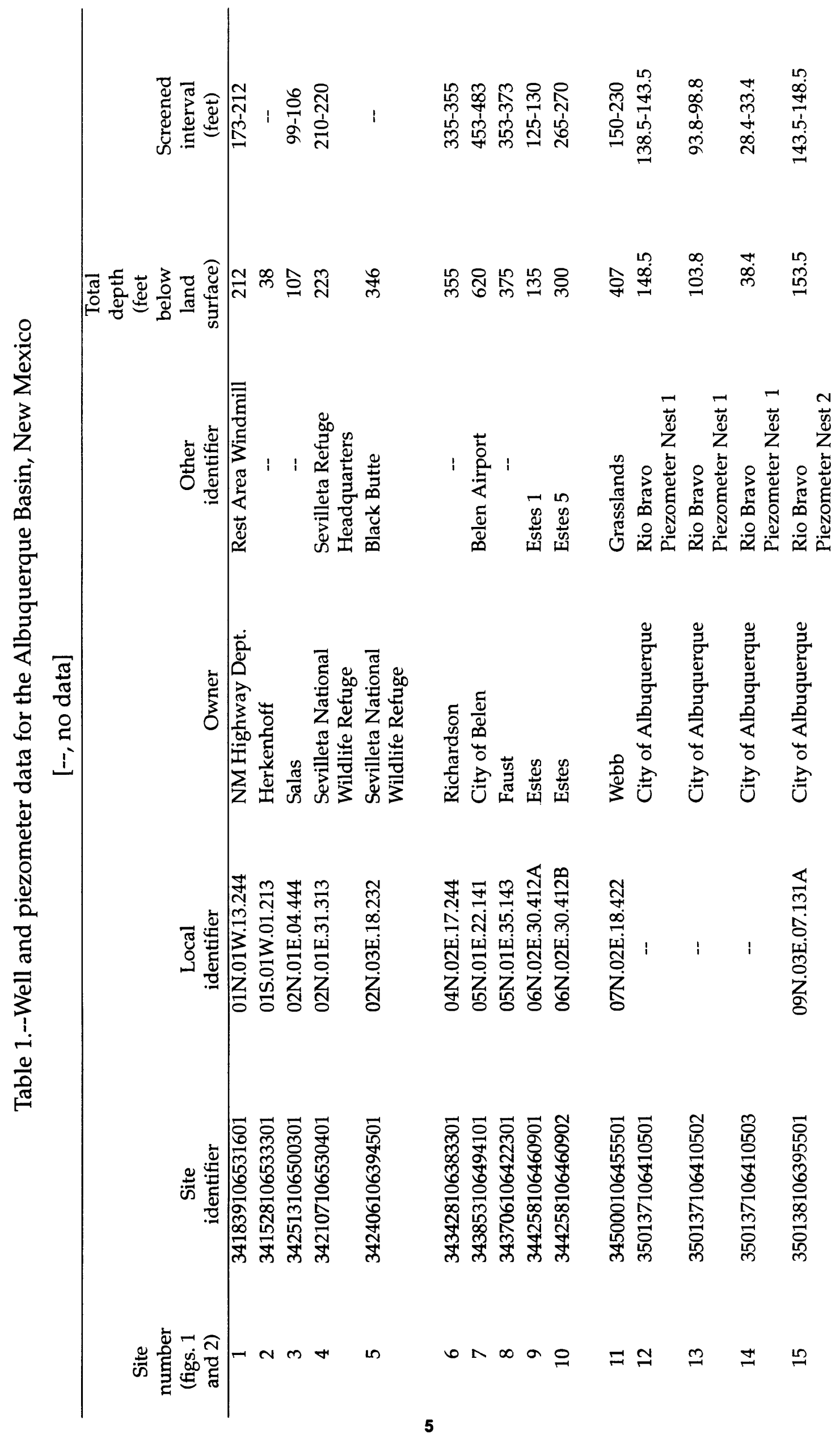




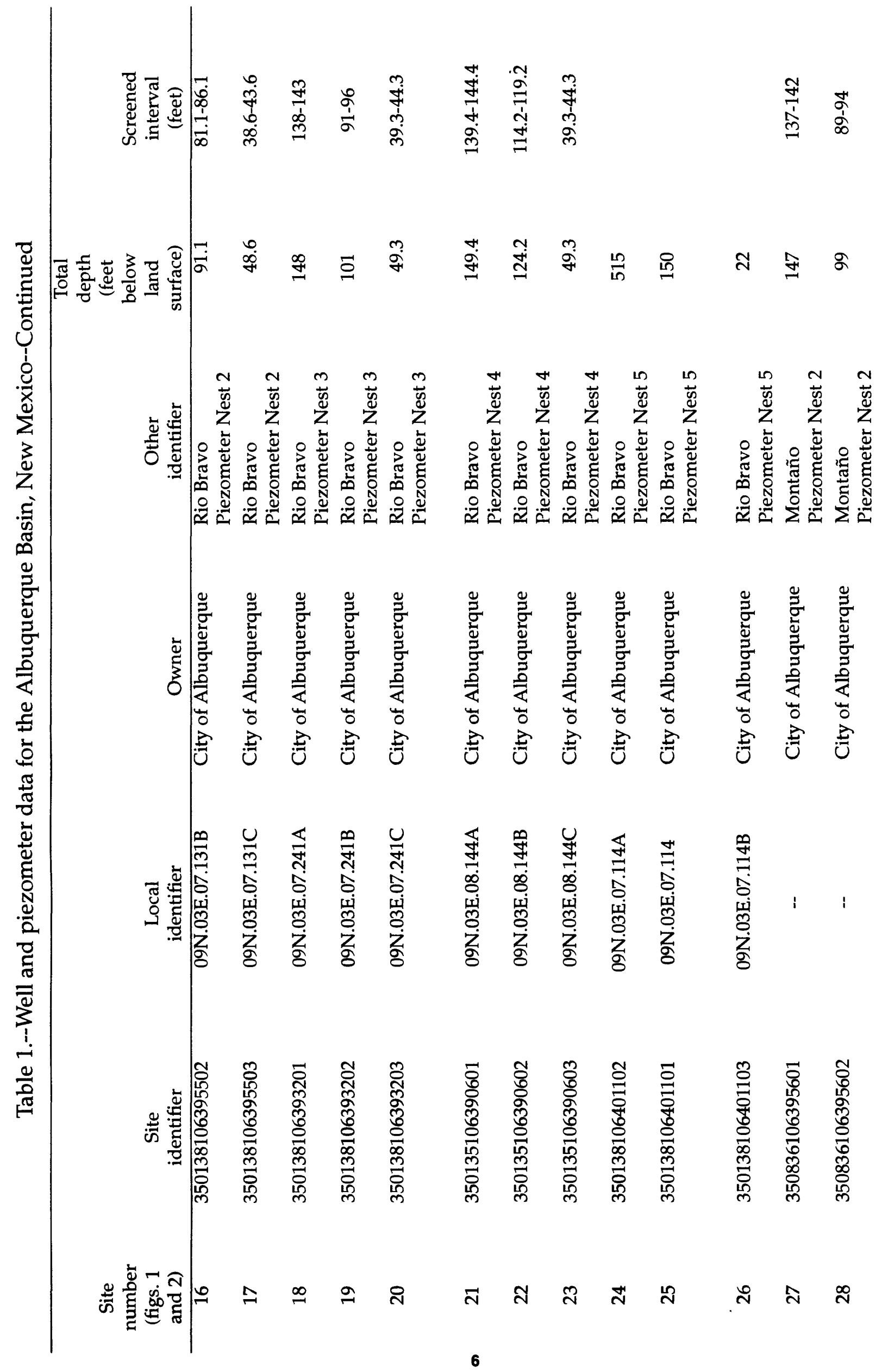




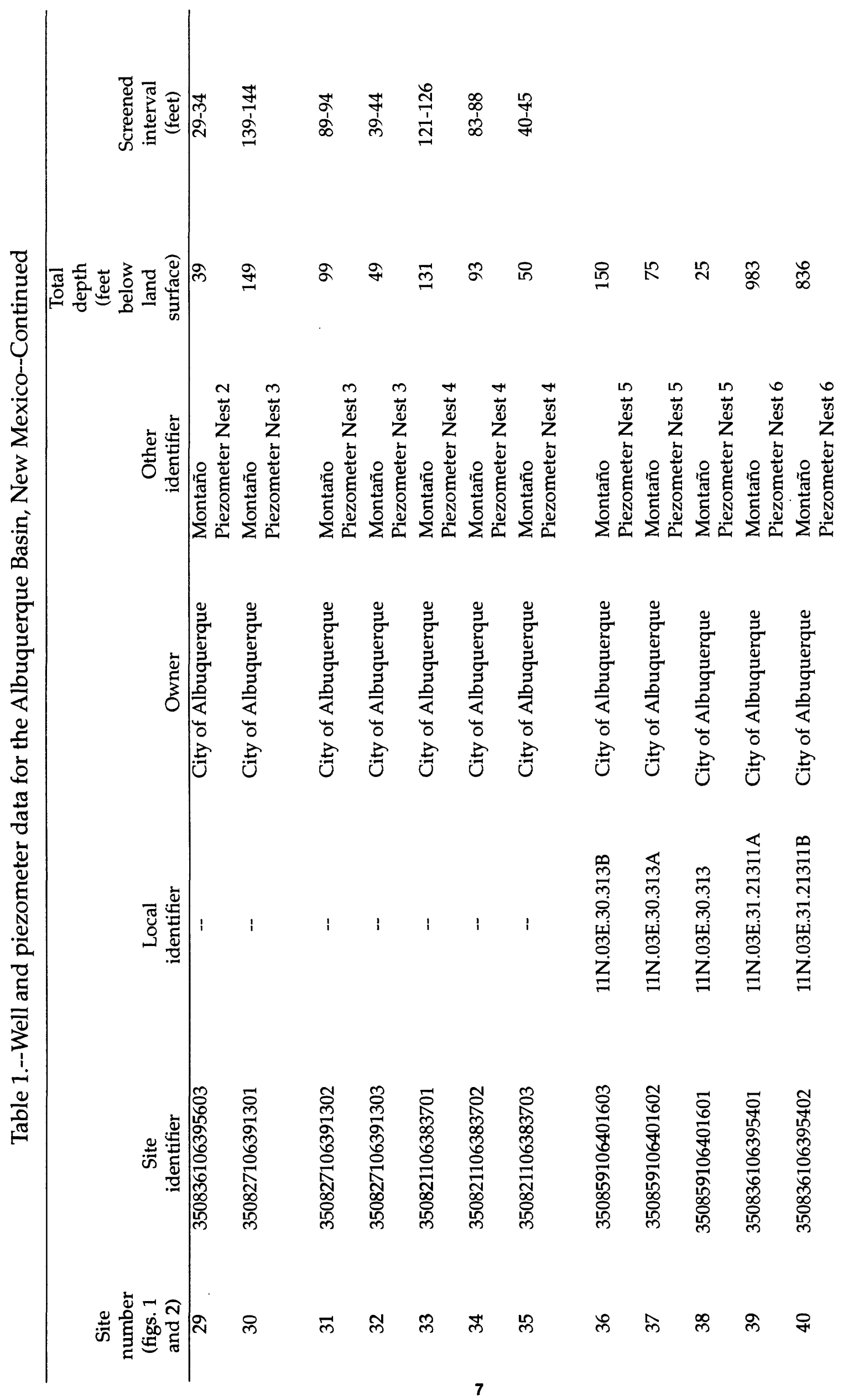




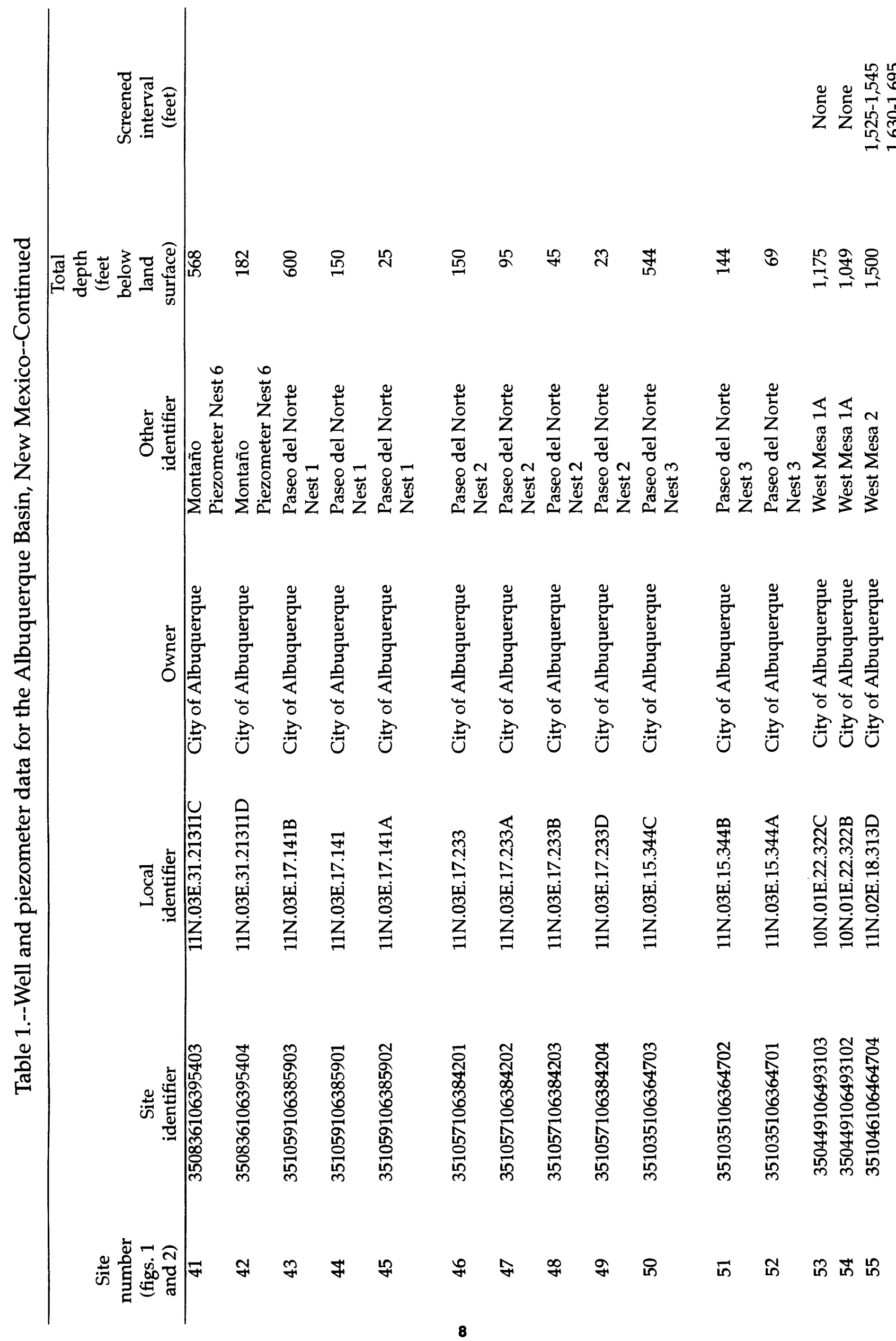




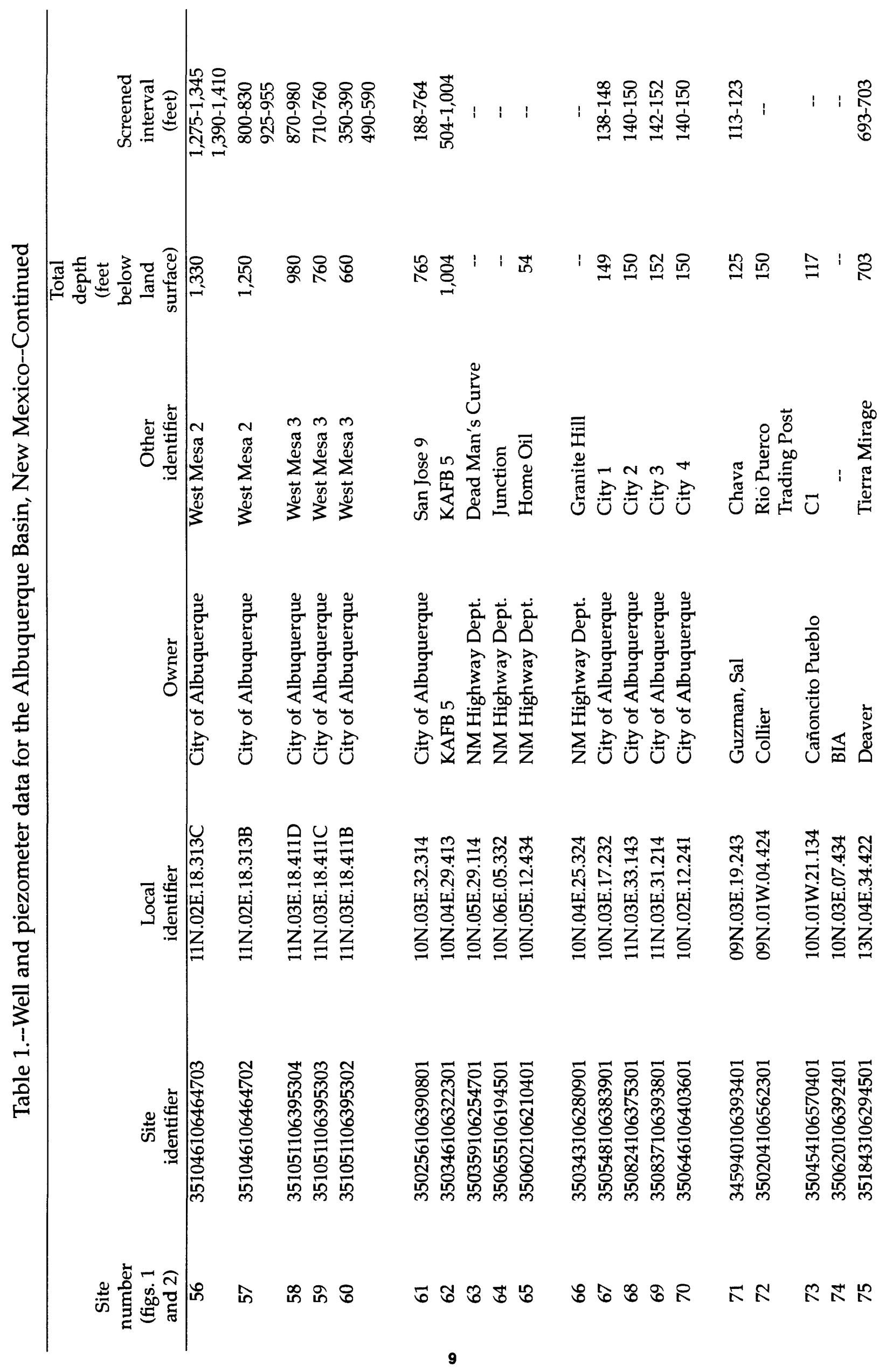




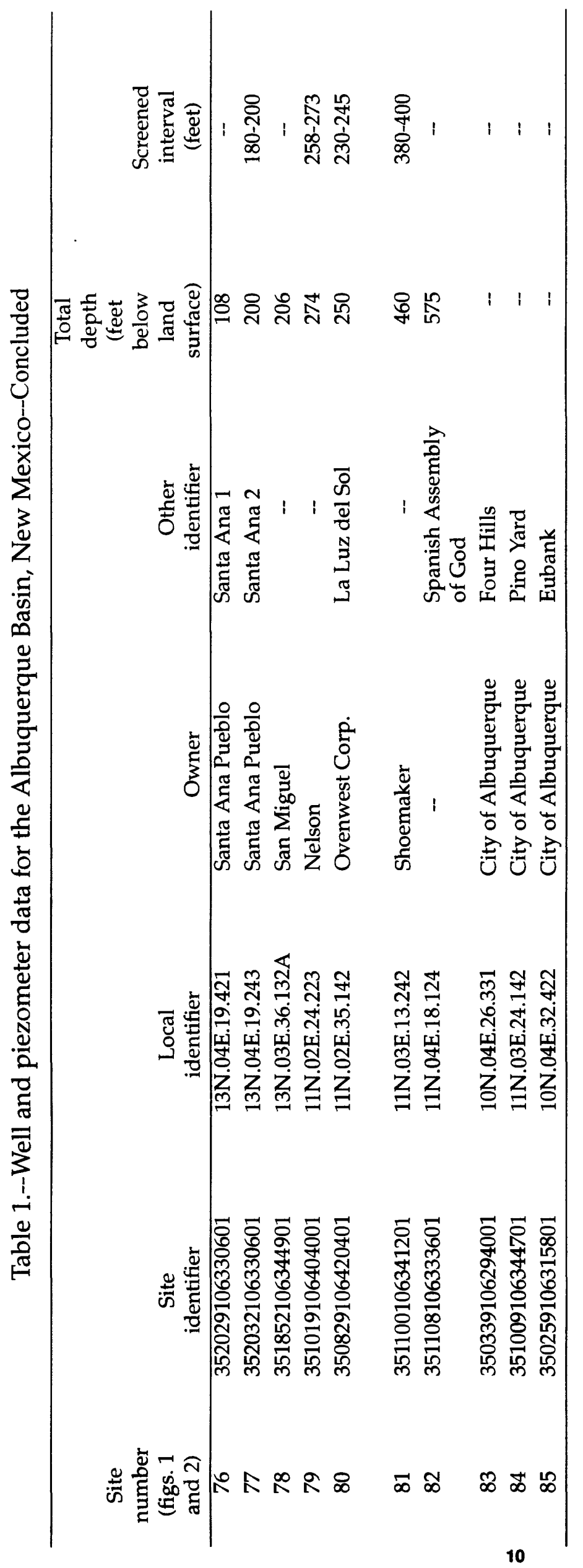




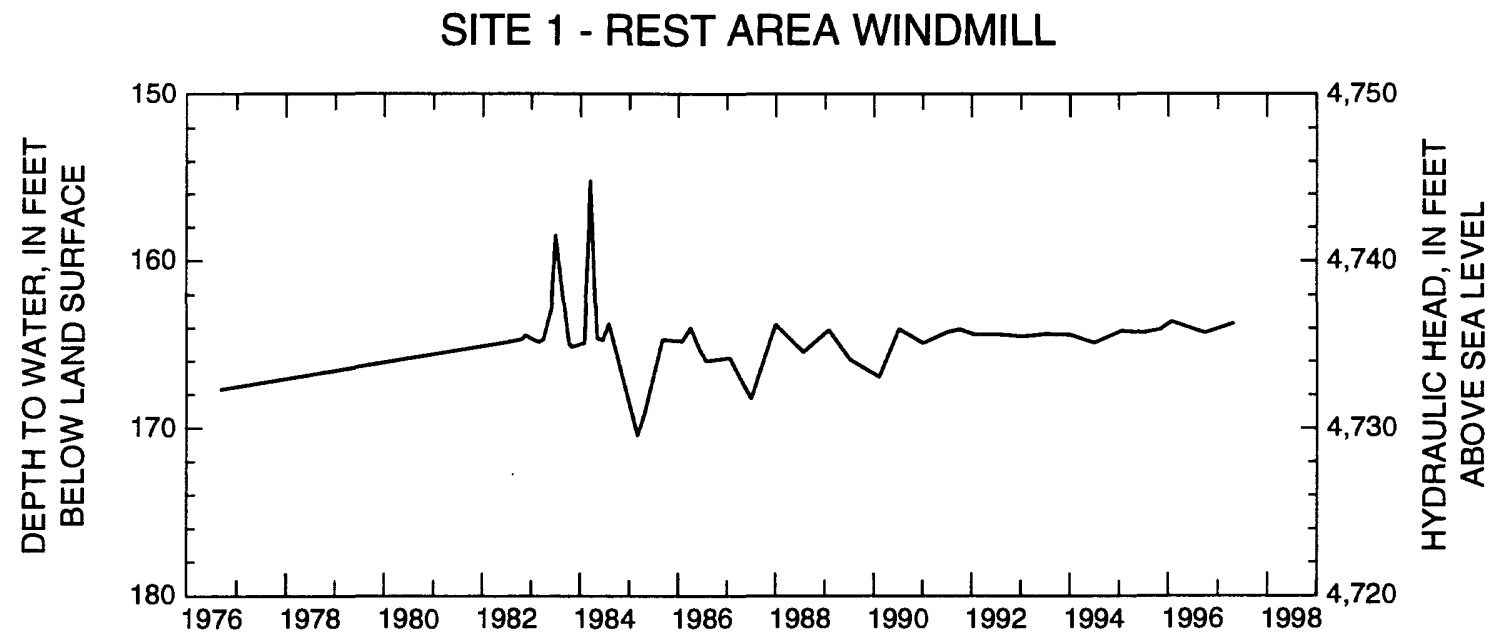

SITE 2 - HERKENHOFF

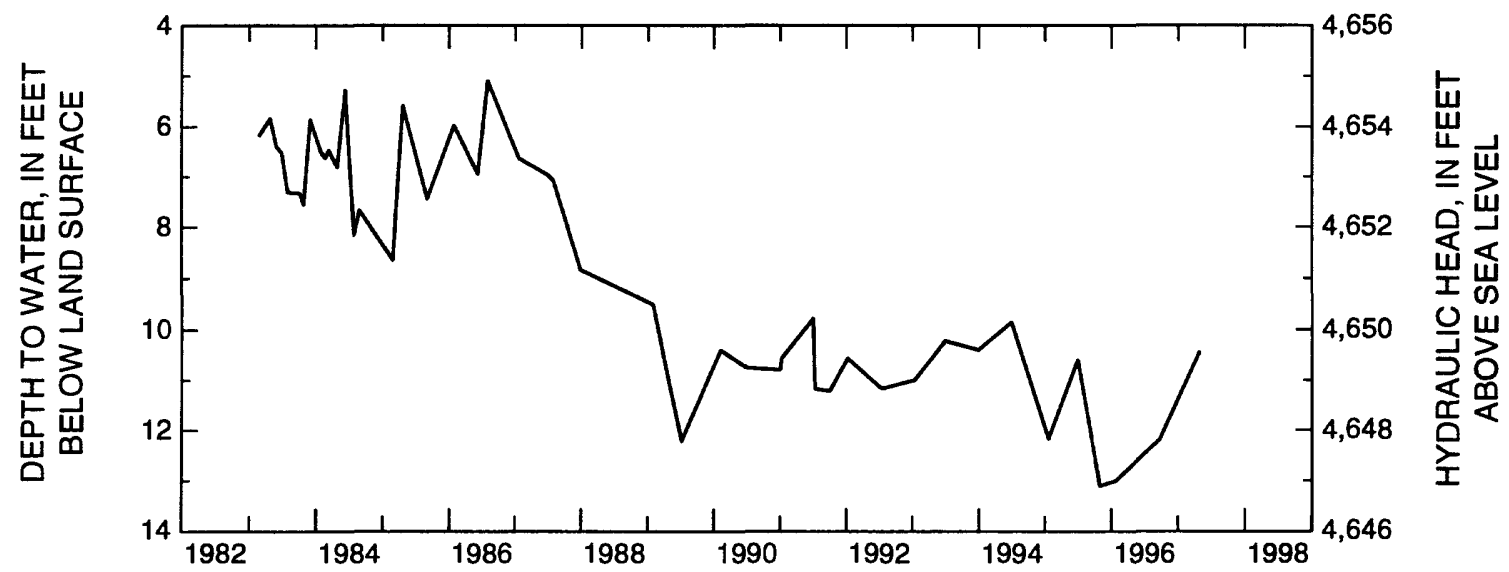

SITE 3 - SALAS

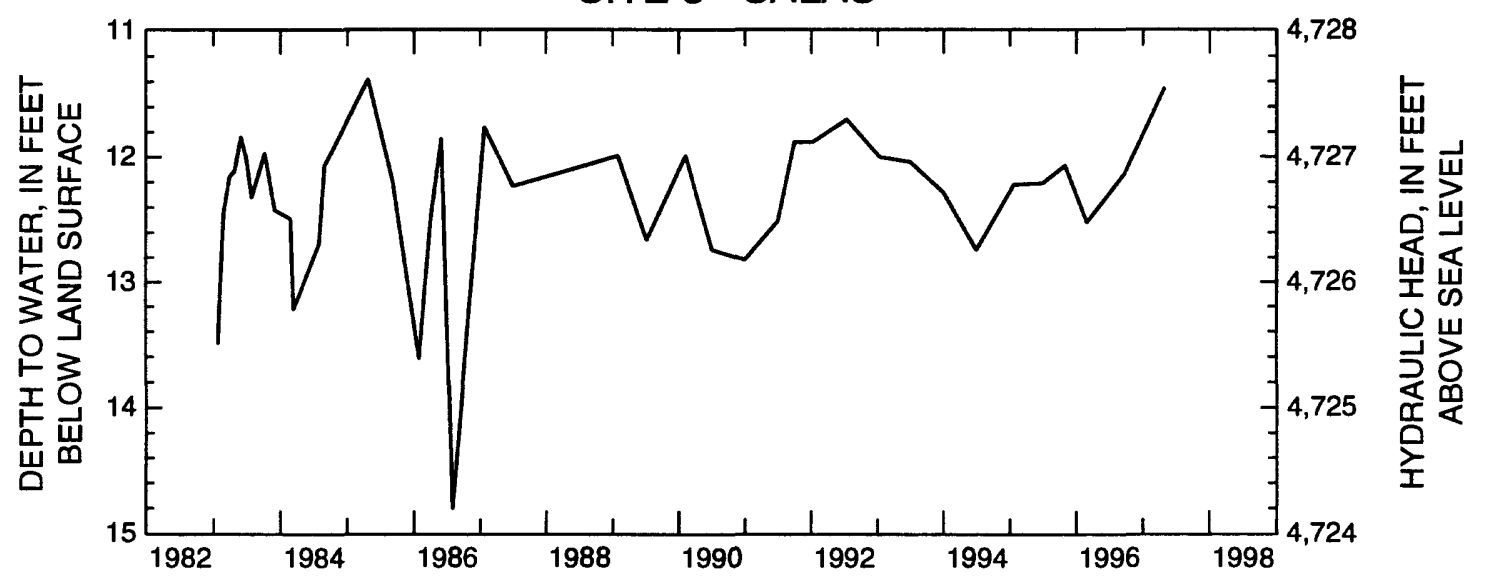

Figure 4.--Water-level data for selected wells and piezometers in the Albuquerque Basin. 
SITE 4 - SEVILLETA REFUGE HEADQUARTERS

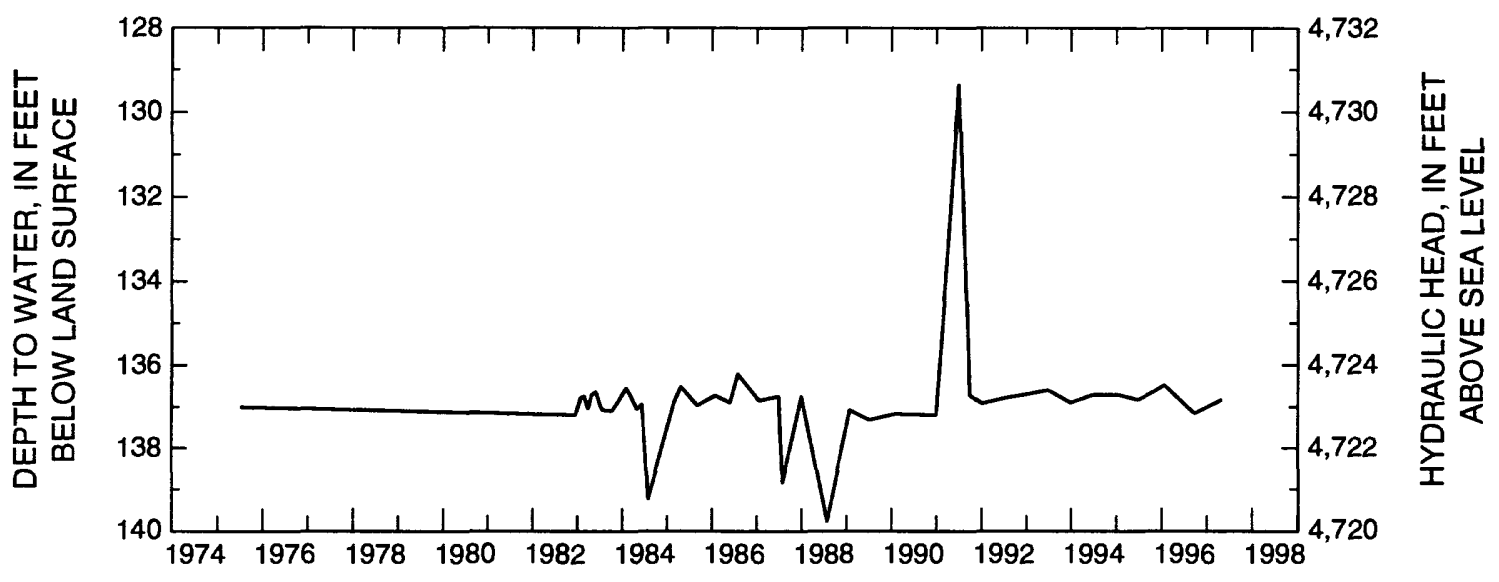

SITE 5 - BLACK BUTTE

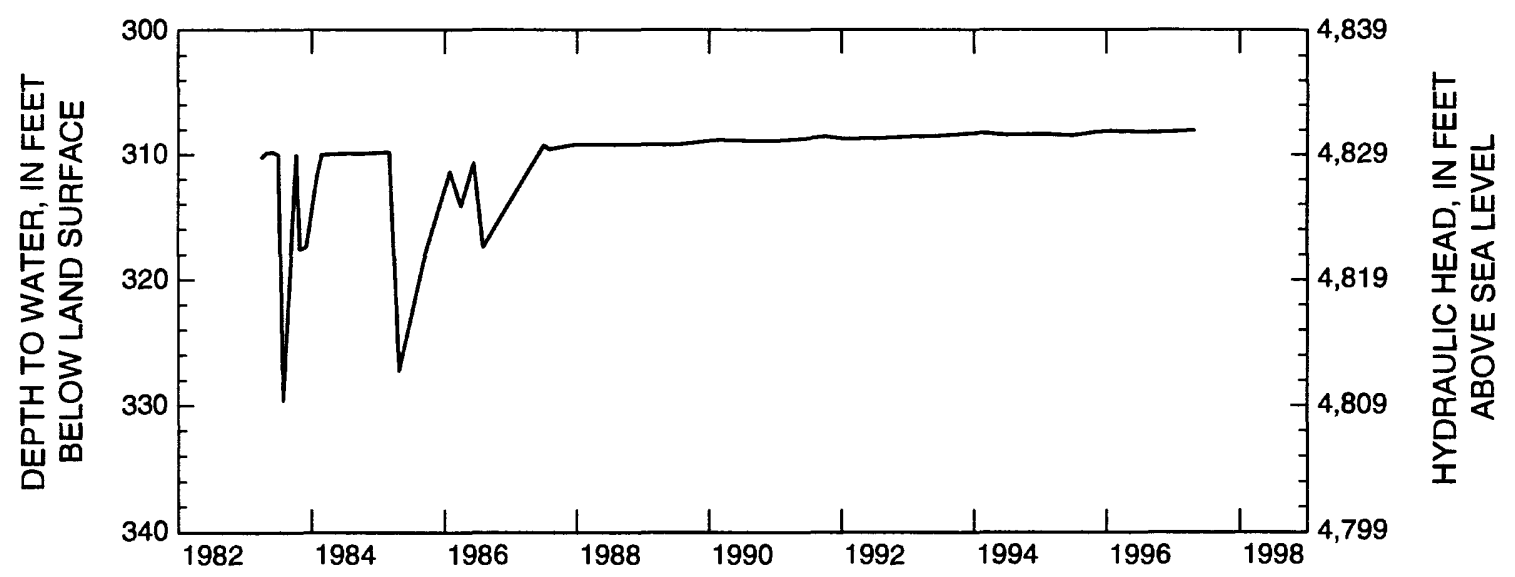

SITE 6 - RICHARDSON

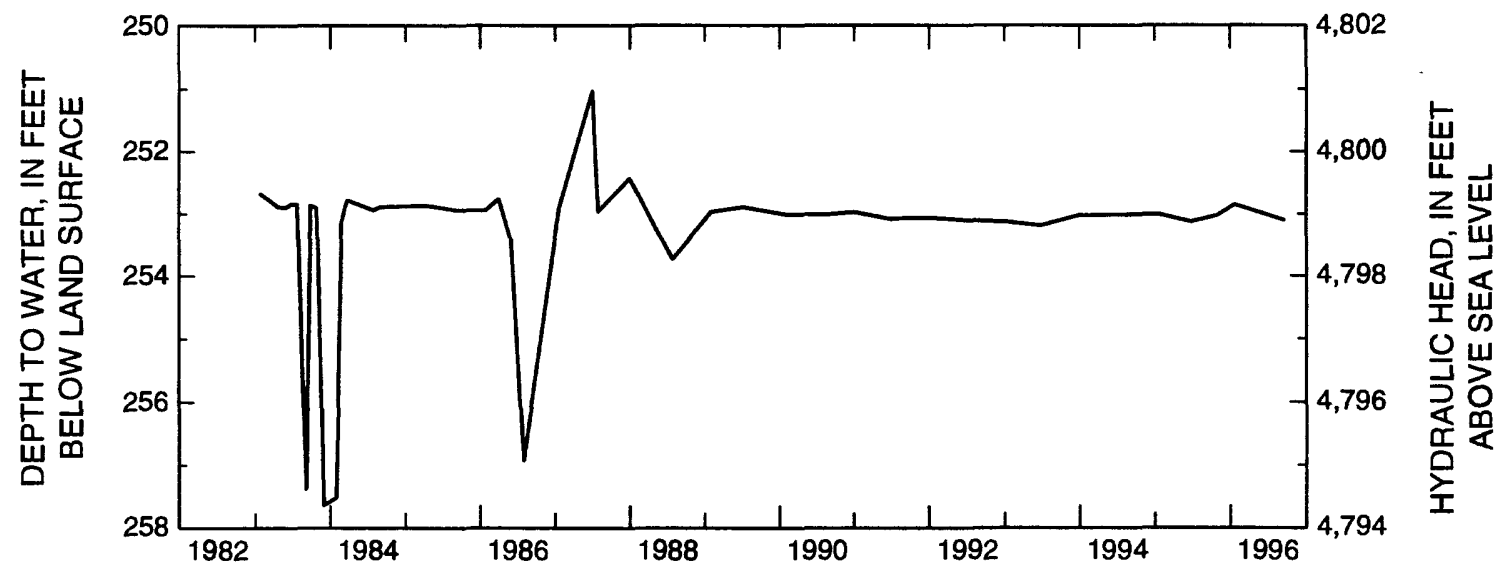

Figure 4.--Water-level data for selected wells and piezometers in the Albuquerque Basin--Continued. 
SITE 7 - BELEN AIRPORT

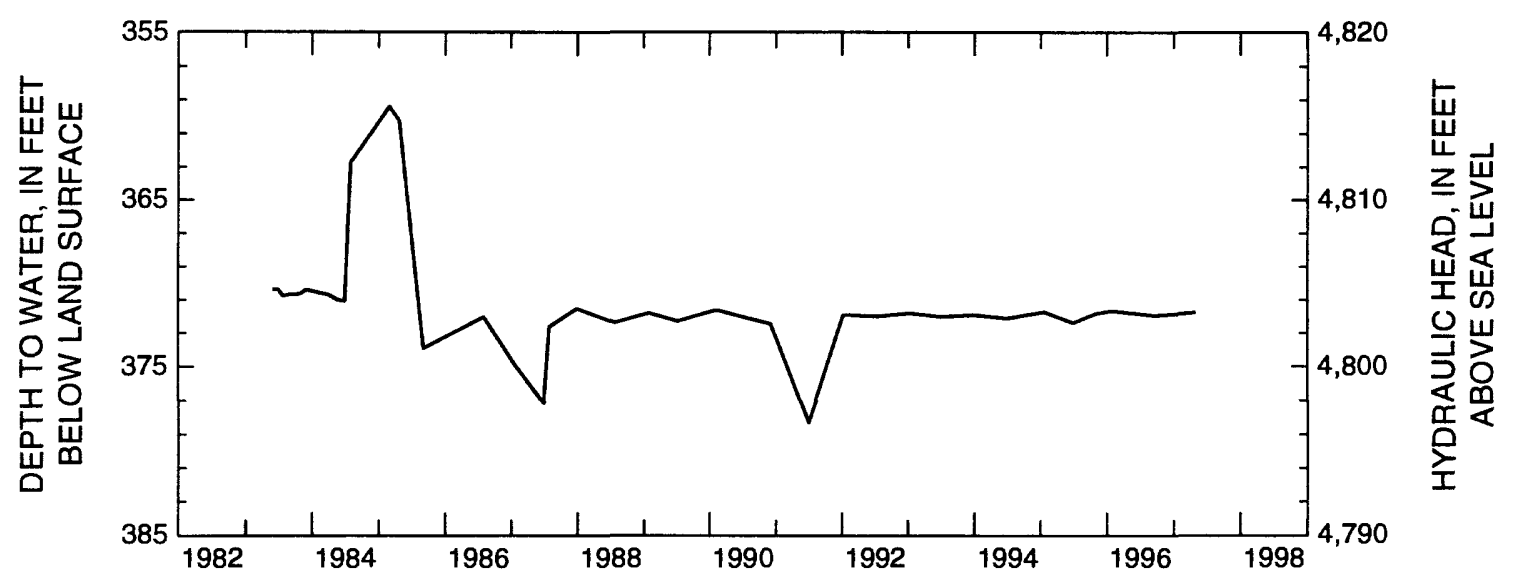

SITE 8 - FAUST

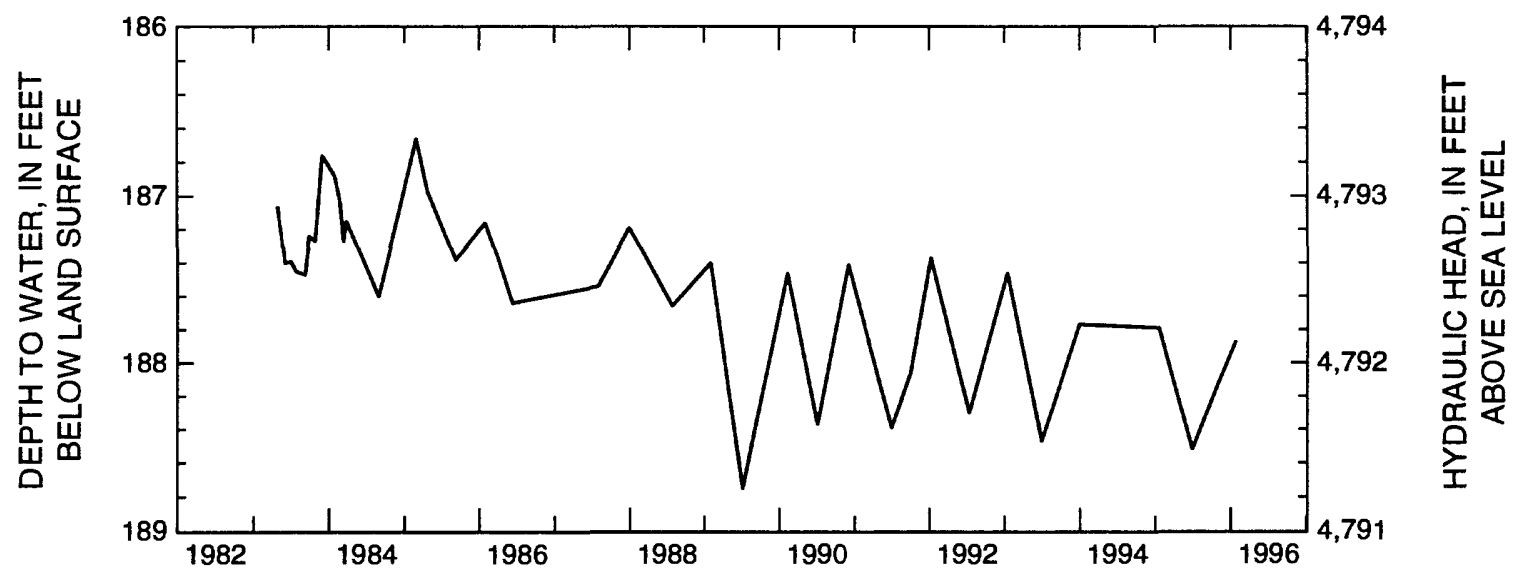

SITE 9 - ESTES 1

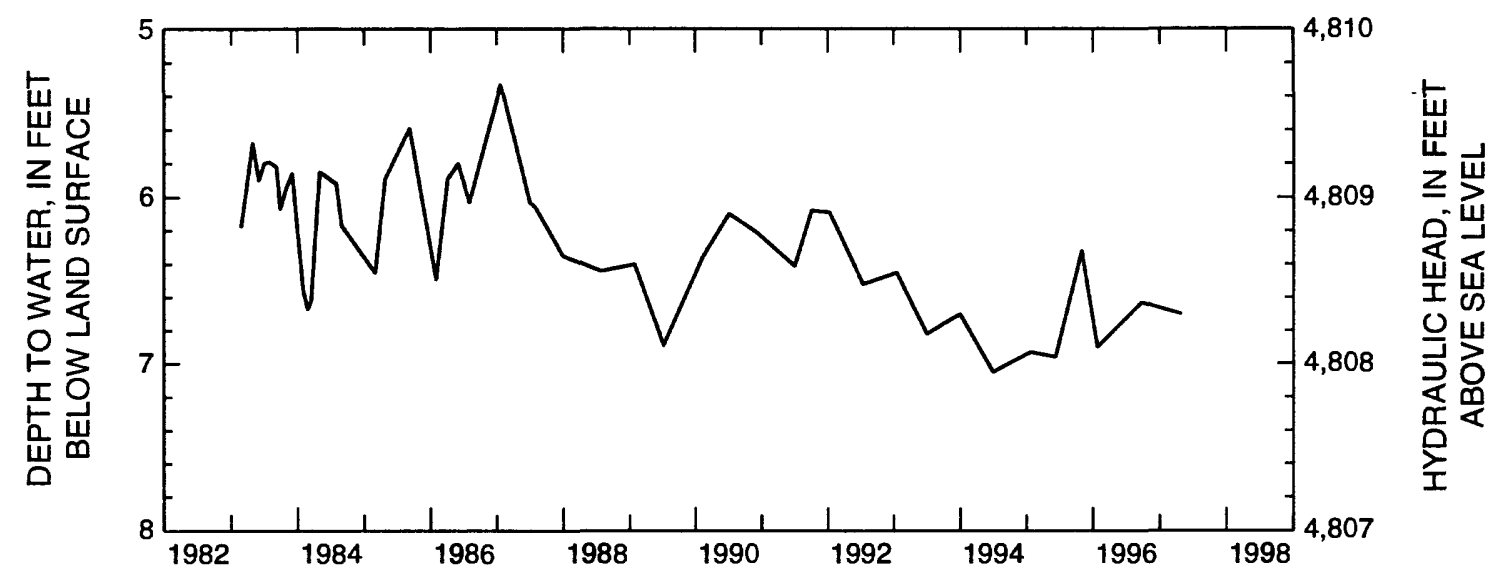

Figure 4.--Water-level data for selected wells and piezometers in the Albuquerque Basin-Continued. 
SITE 10 - ESTES 5

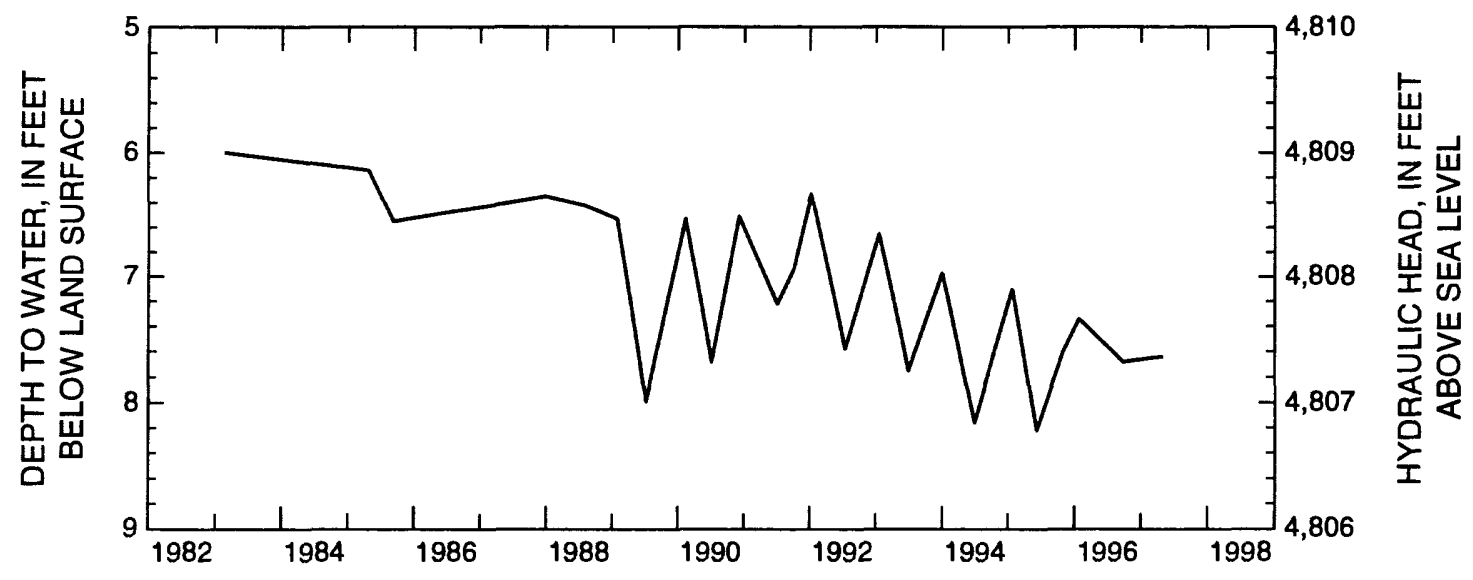

SITE 11 - GRASSLANDS

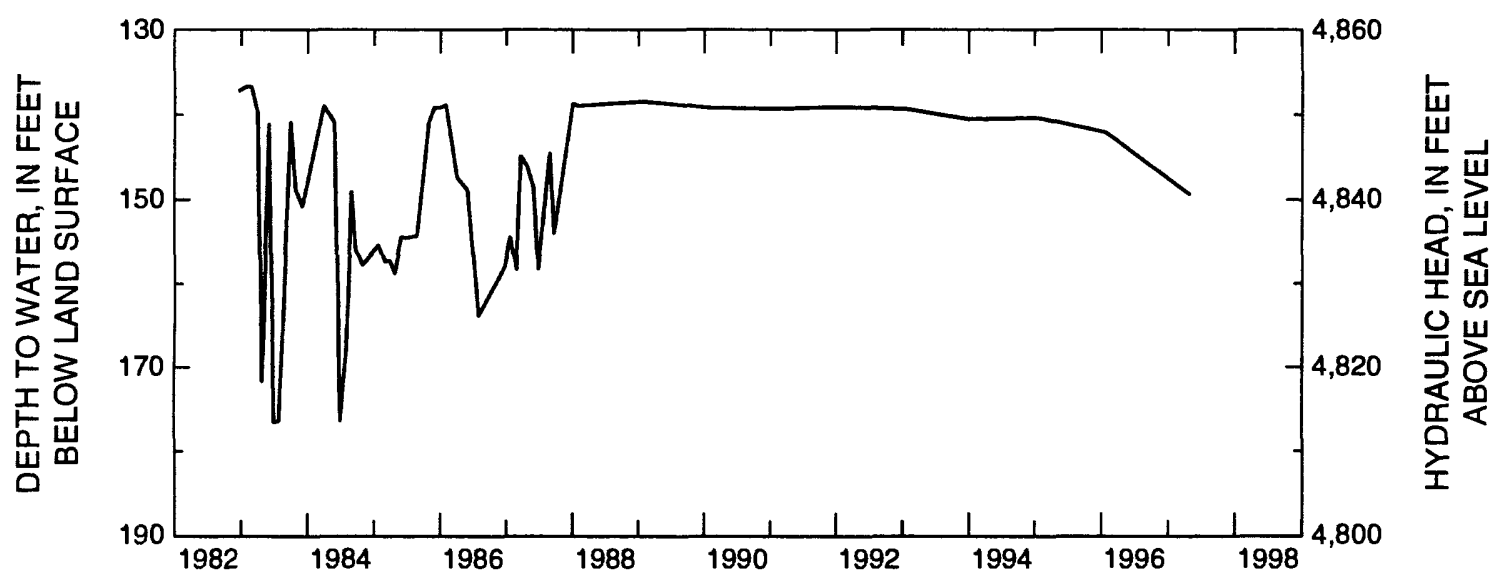

SITES 12, 13, 14 - RIO BRAVO NEST 1

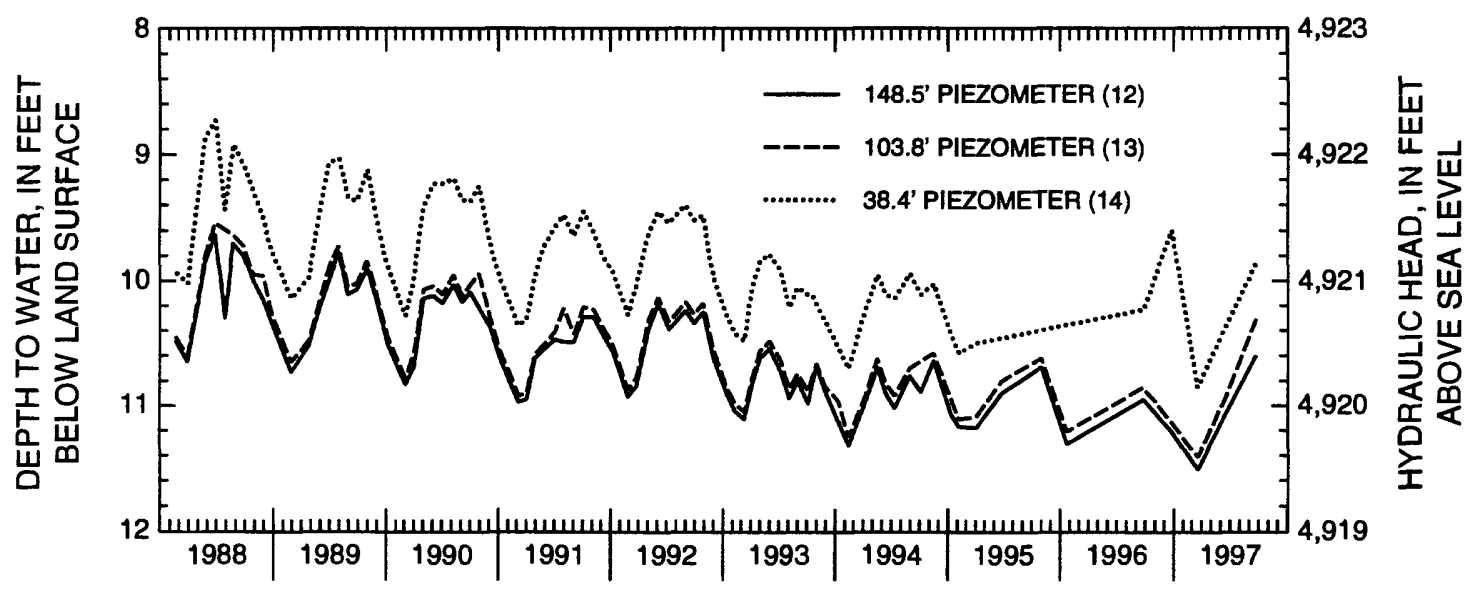

Figure 4.--Water-level data for selected wells and piezometers in the Albuquerque Basin--Continued. 
SITES 15, 16, 17 - RIO BRAVO NEST 2
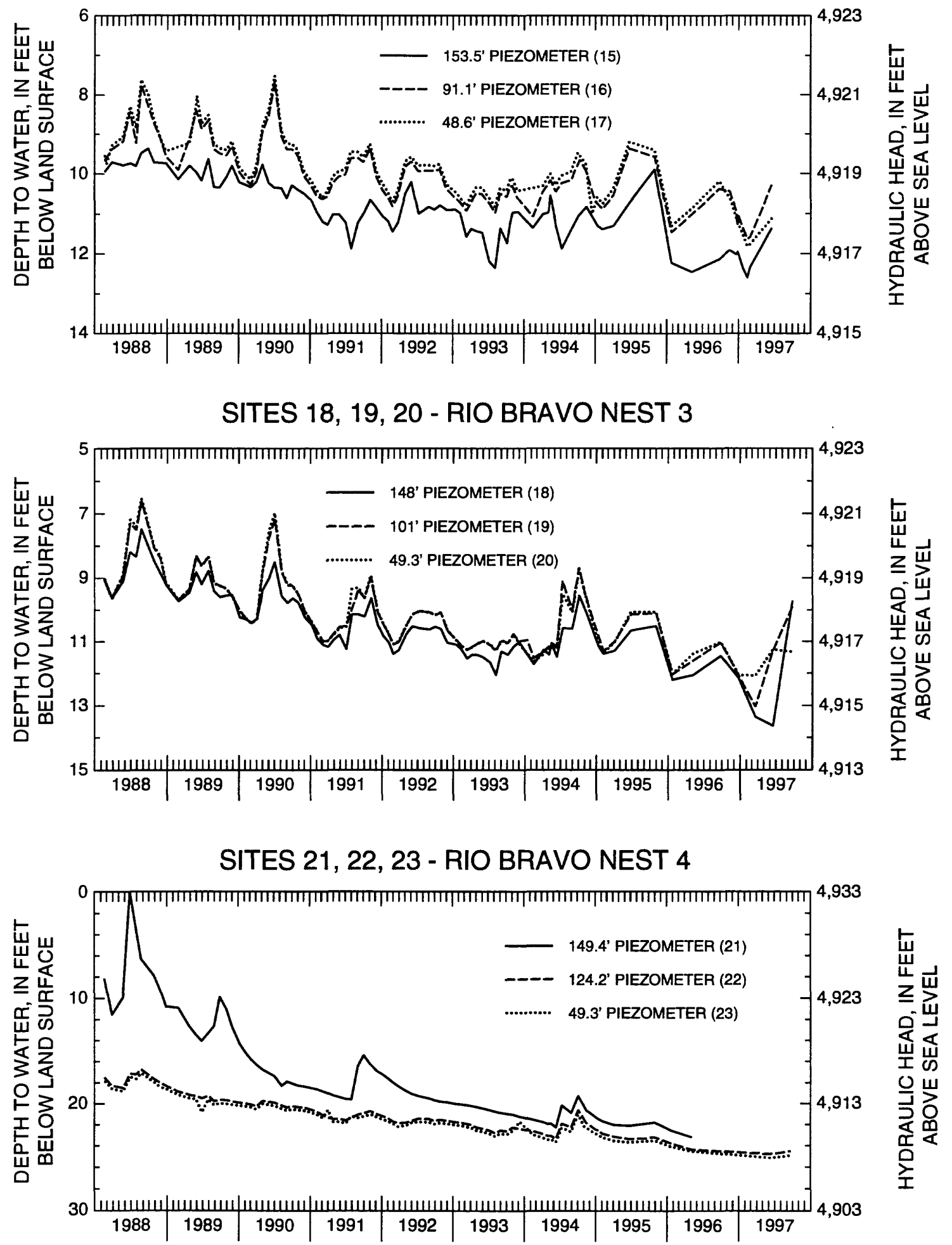

Figure 4.--Water-level data for selected wells and piezometers in the Albuquerque Basin--Continued. 


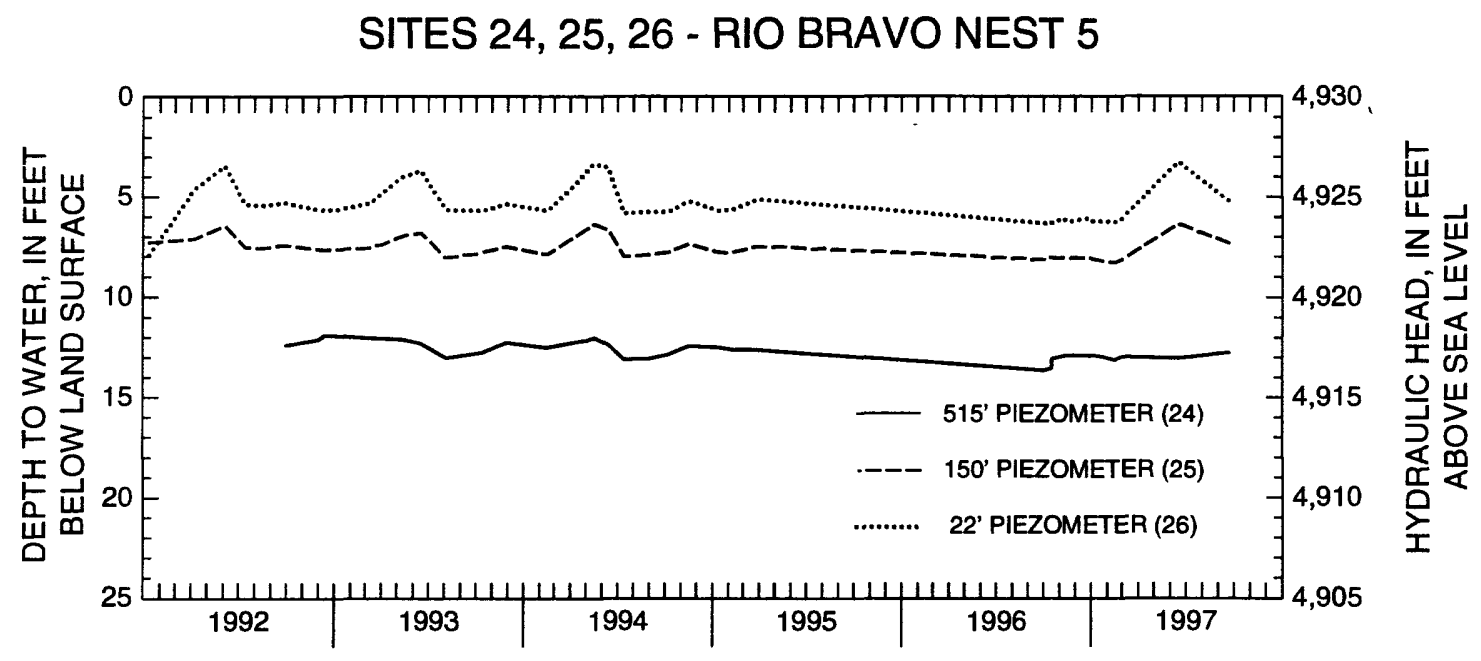

\section{SITES 27, 28, 29 - MONTAÑNO NEST 2}

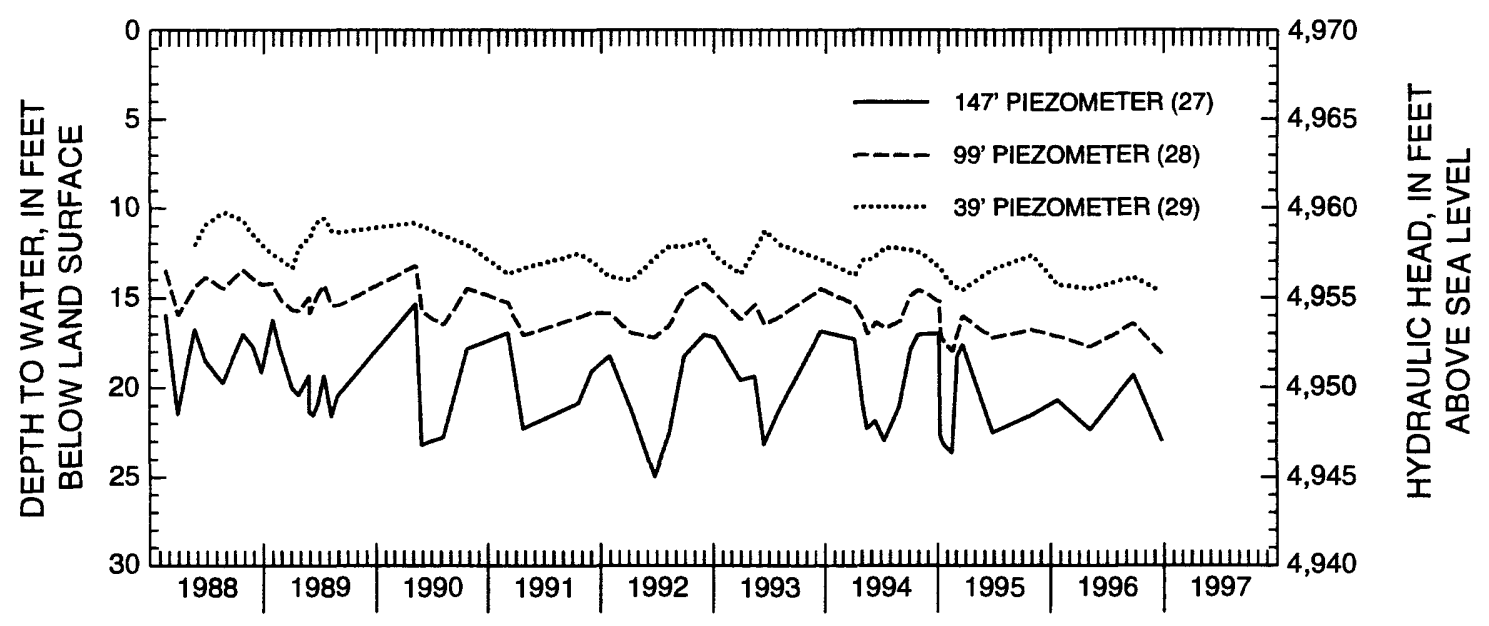

\section{SITES 30, 31, 32 - MONTAÑO NEST 3}

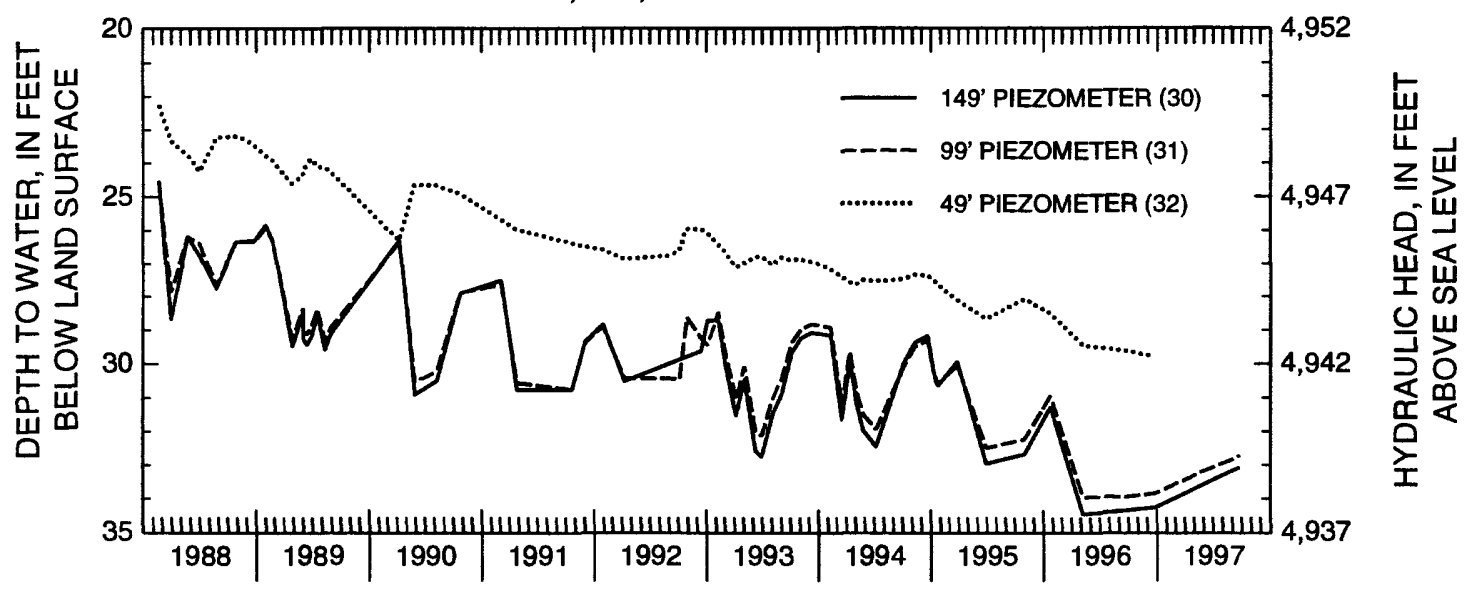

Figure 4.--Water-level data for selected wells and piezometers in the Albuquerque Basin--Continued. 


\section{SITES 33, 34, 35 - MONTAÑO NEST 4}
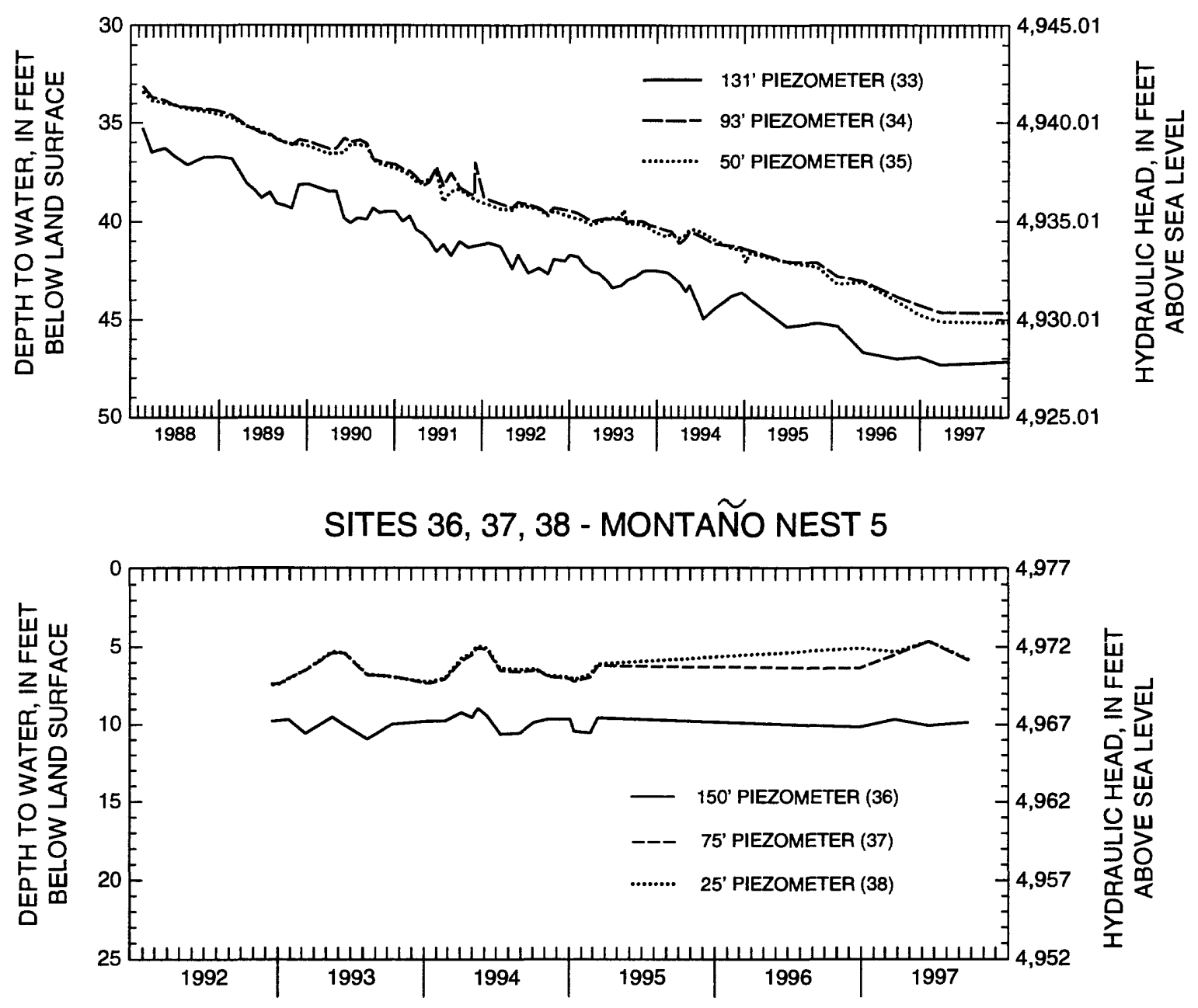

SITES 39, 40, 41, 42 - MONTAÑNO NEST 6

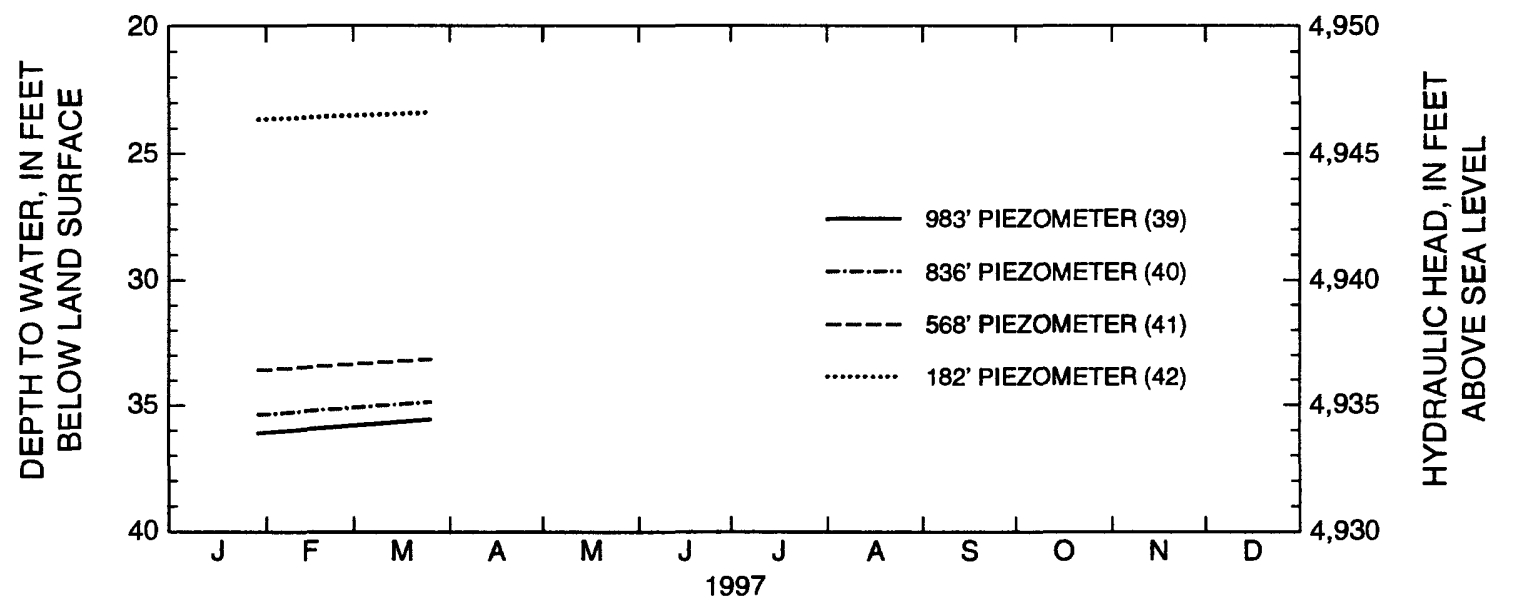

Figure 4.--Water-level data for selected wells and piezometers in the Albuquerque Basin--Continued. 


\section{SITE 43, 44, 45 - PASEO DEL NORTE NEST 1}

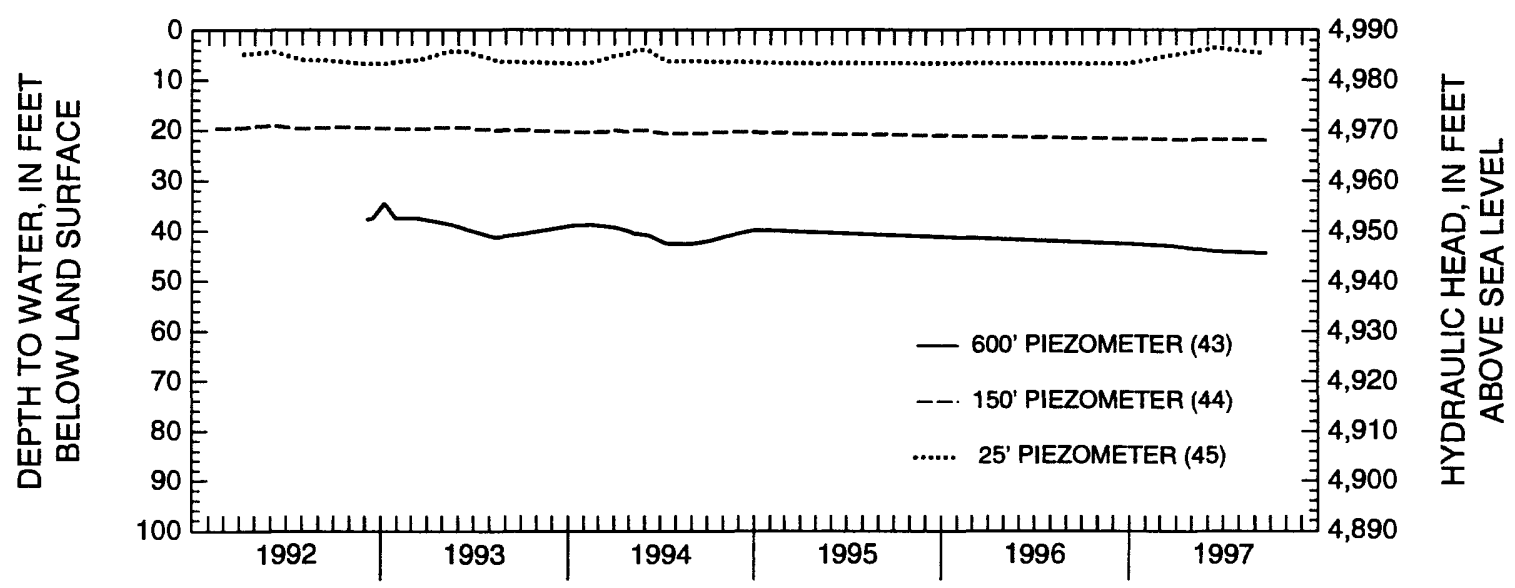

SITES 46, 47, 48, 49 - PASEO DEL NORTE NEST 2

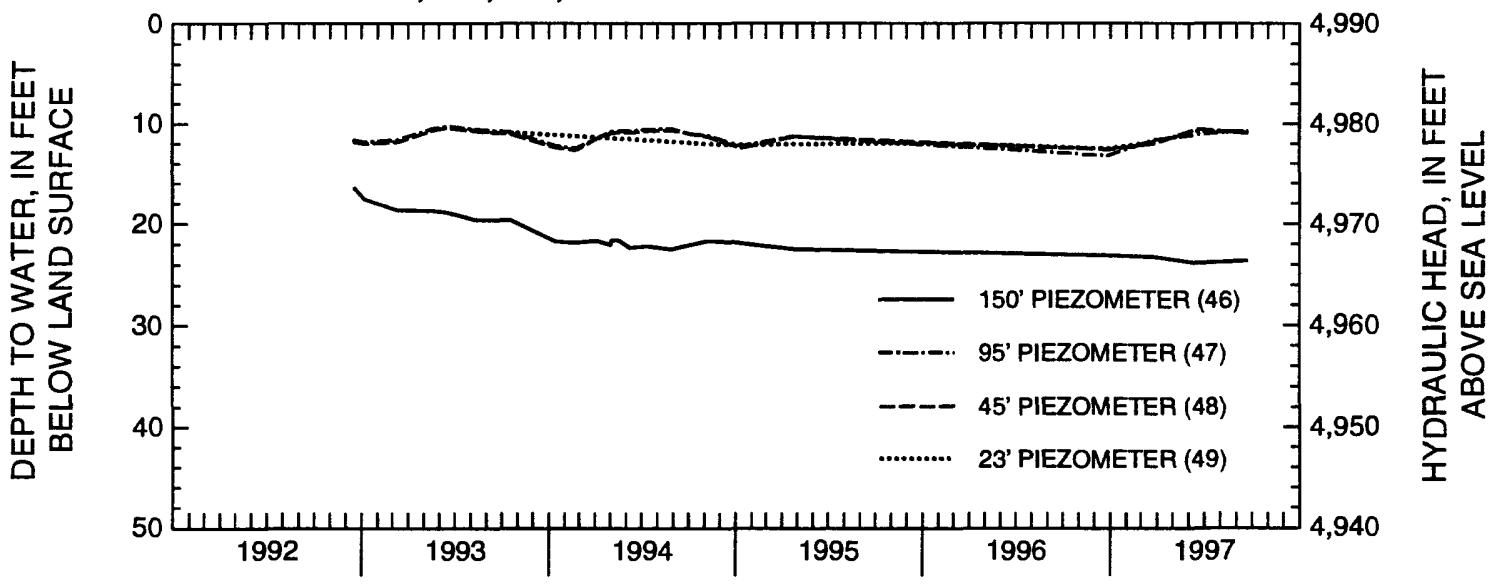

SITES 50, 51, 52 - PASEO DEL NORTE NEST 3

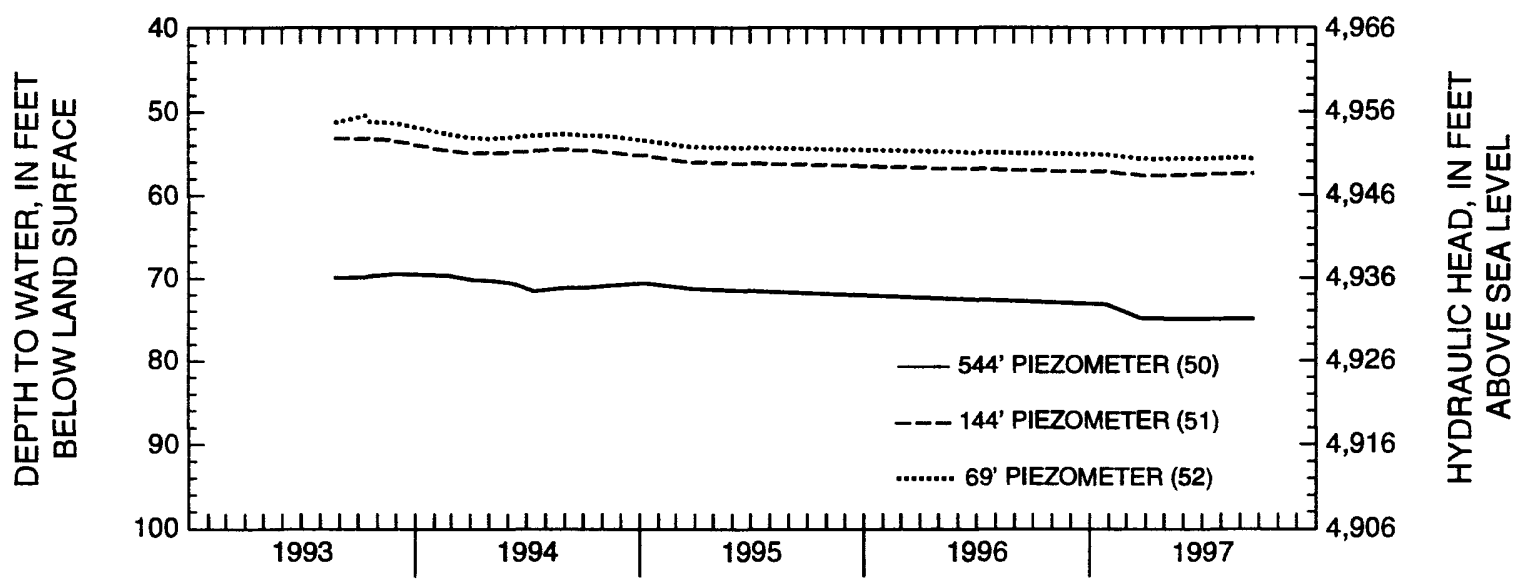

Figure 4.--Water-level data for selected wells and piezometers in the Albuquerque Basin--Continued. 
SITES 53, 54 - WEST MESA NEST 1A

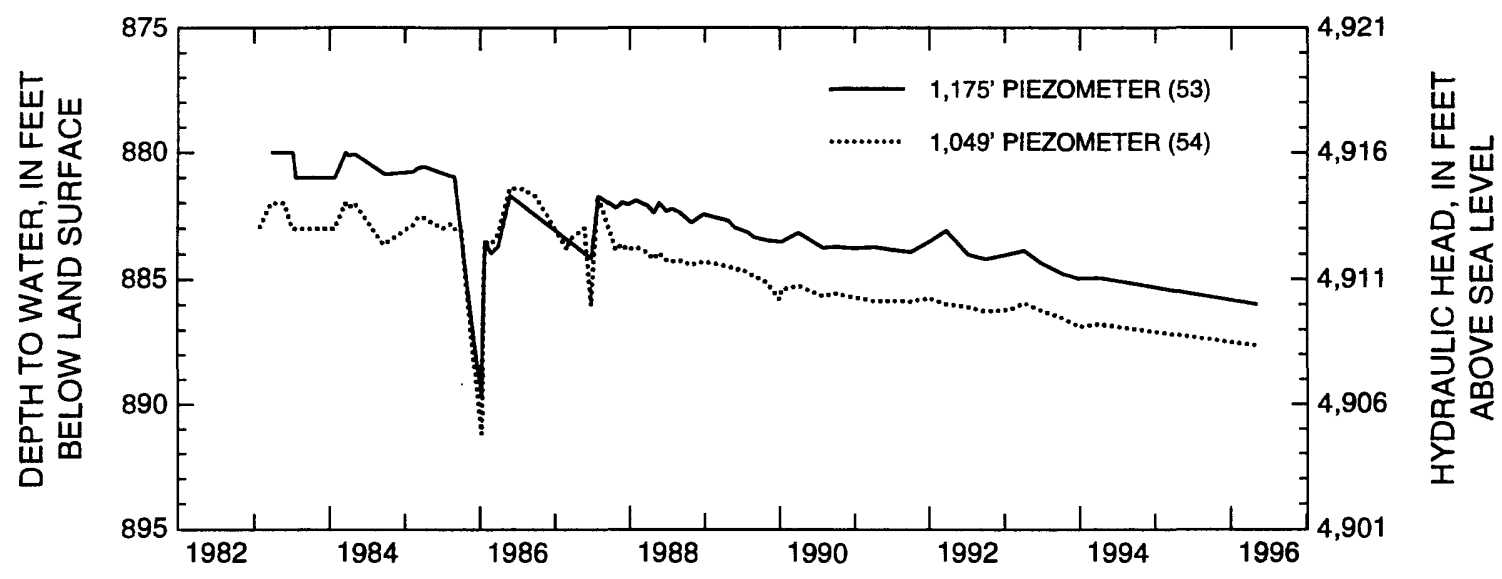

SITES 55, 56, 57 - WEST MESA NEST 2

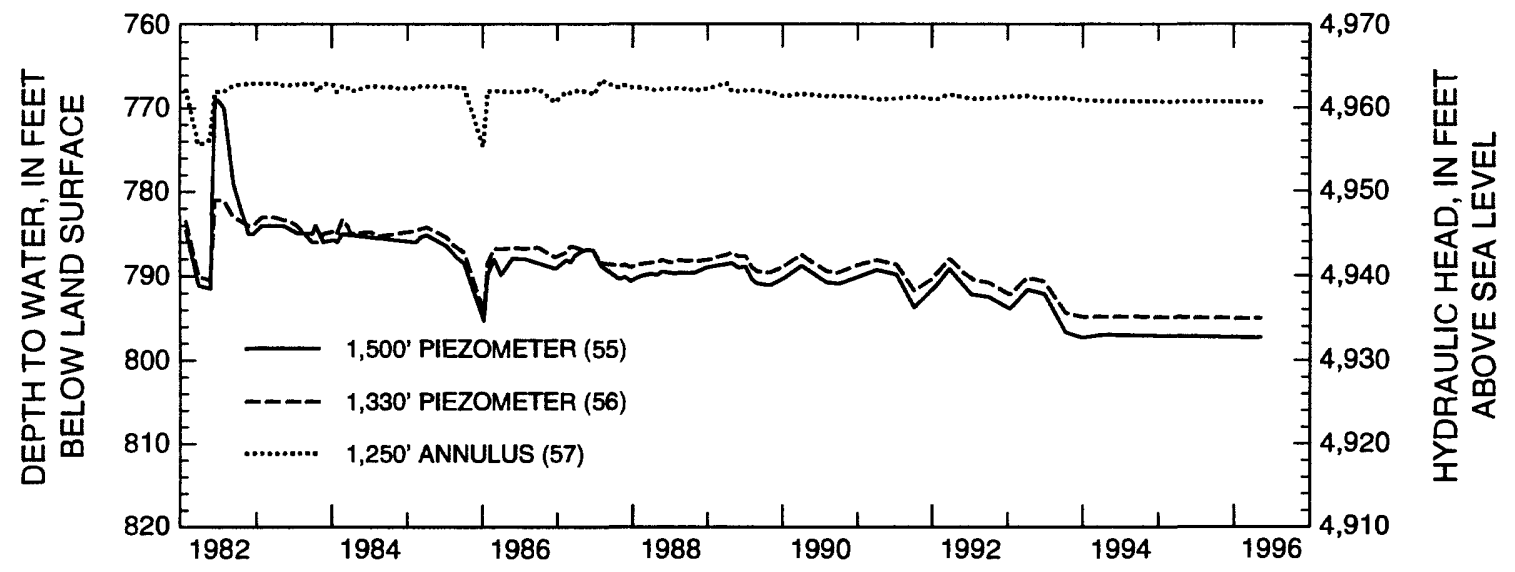

SITES 58, 59, 60 - WEST MESA NEST 3

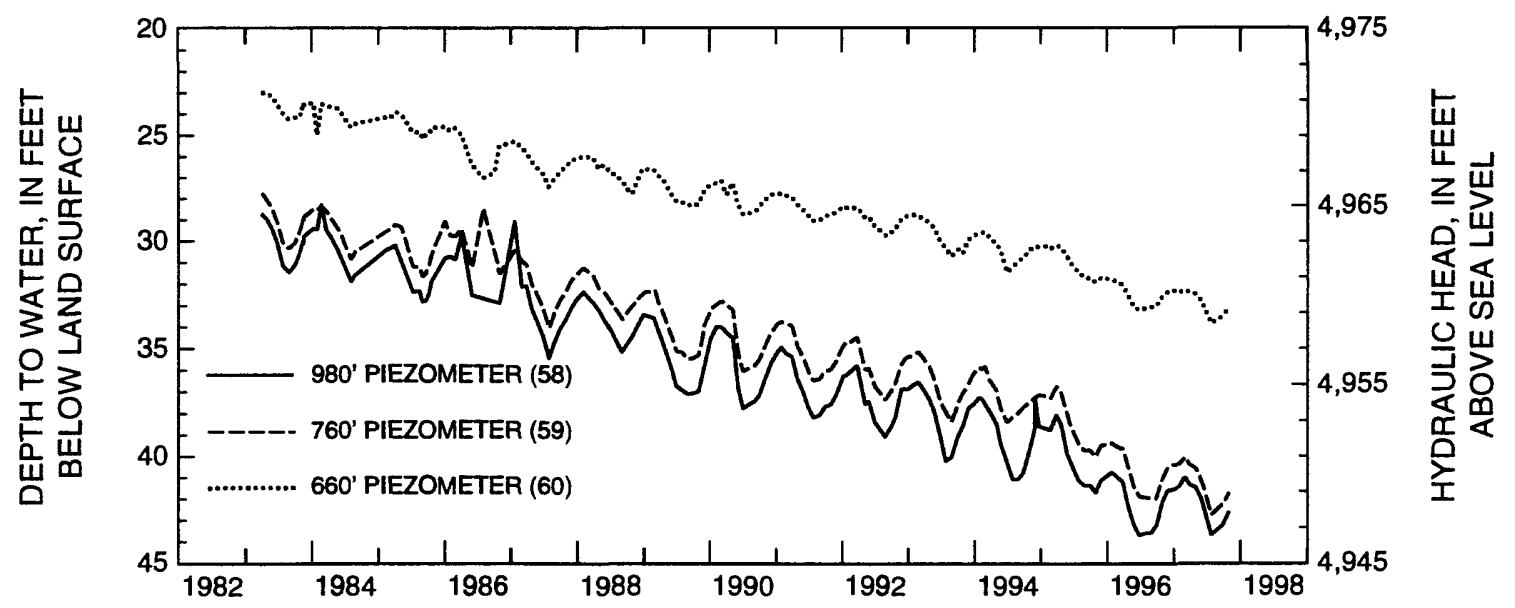

Figure 4.--Water-level data for selected wells and piezometers in the Albuquerque Basin--Continued. 


\section{SITE 61 - SAN JOSE 9}

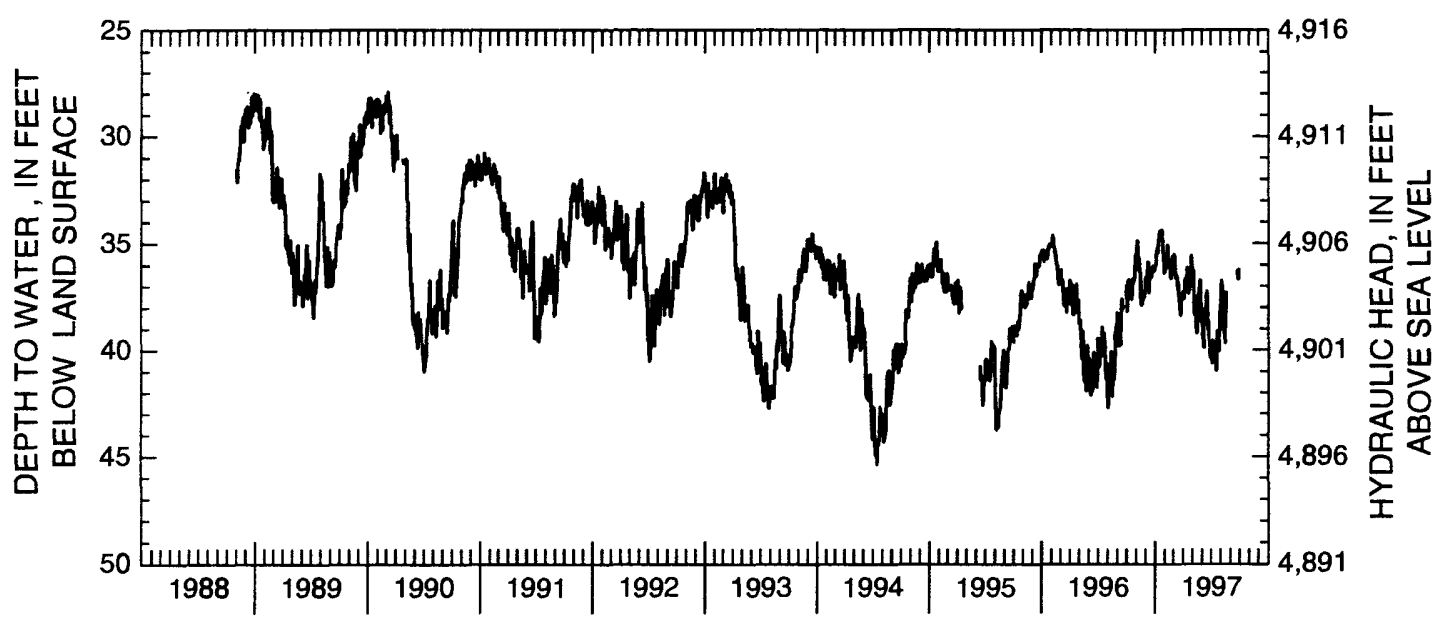

\section{SITE 62 - KAFB 5}

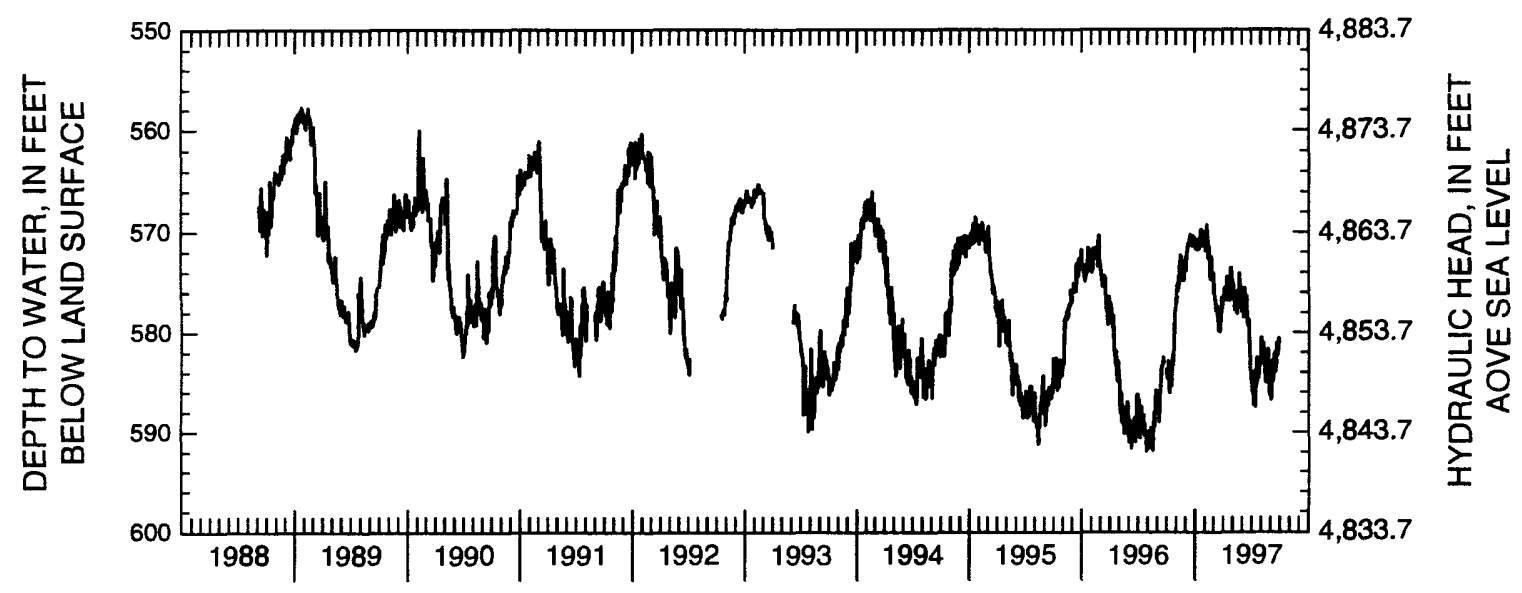

SITE 63 - DEAD MAN'S CURVE

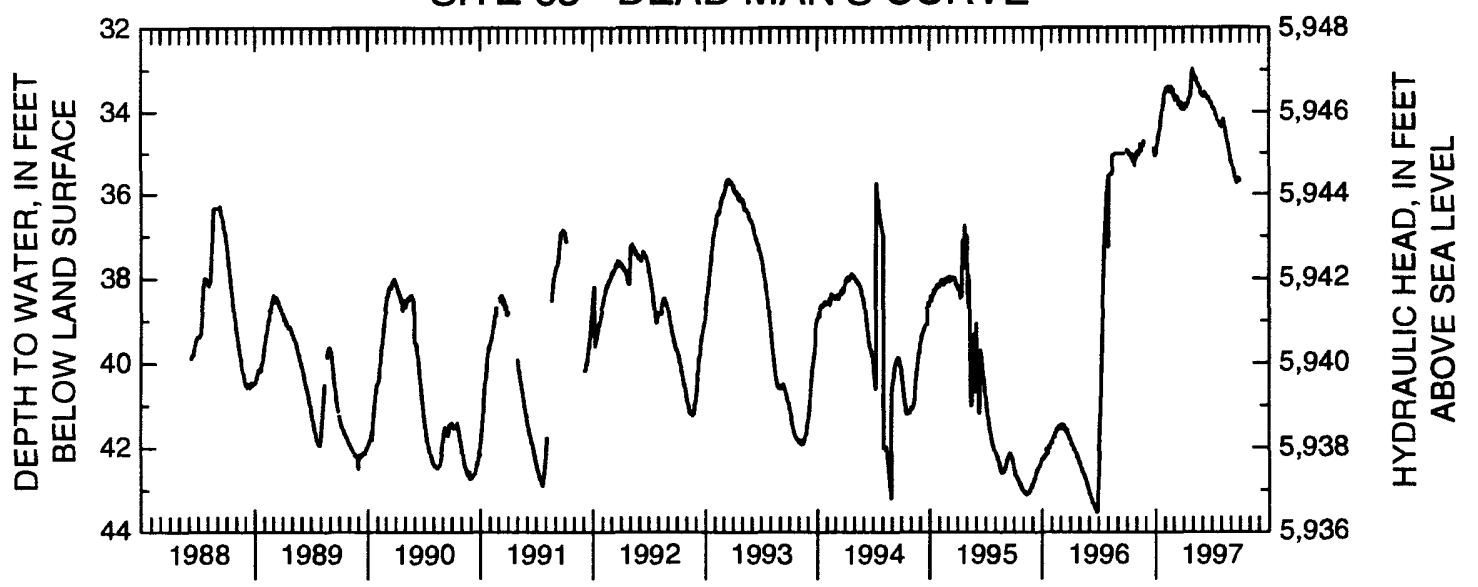

Figure 4.--Water-level data for selected wells and piezometers in the Albuquerque Basin--Continued. 

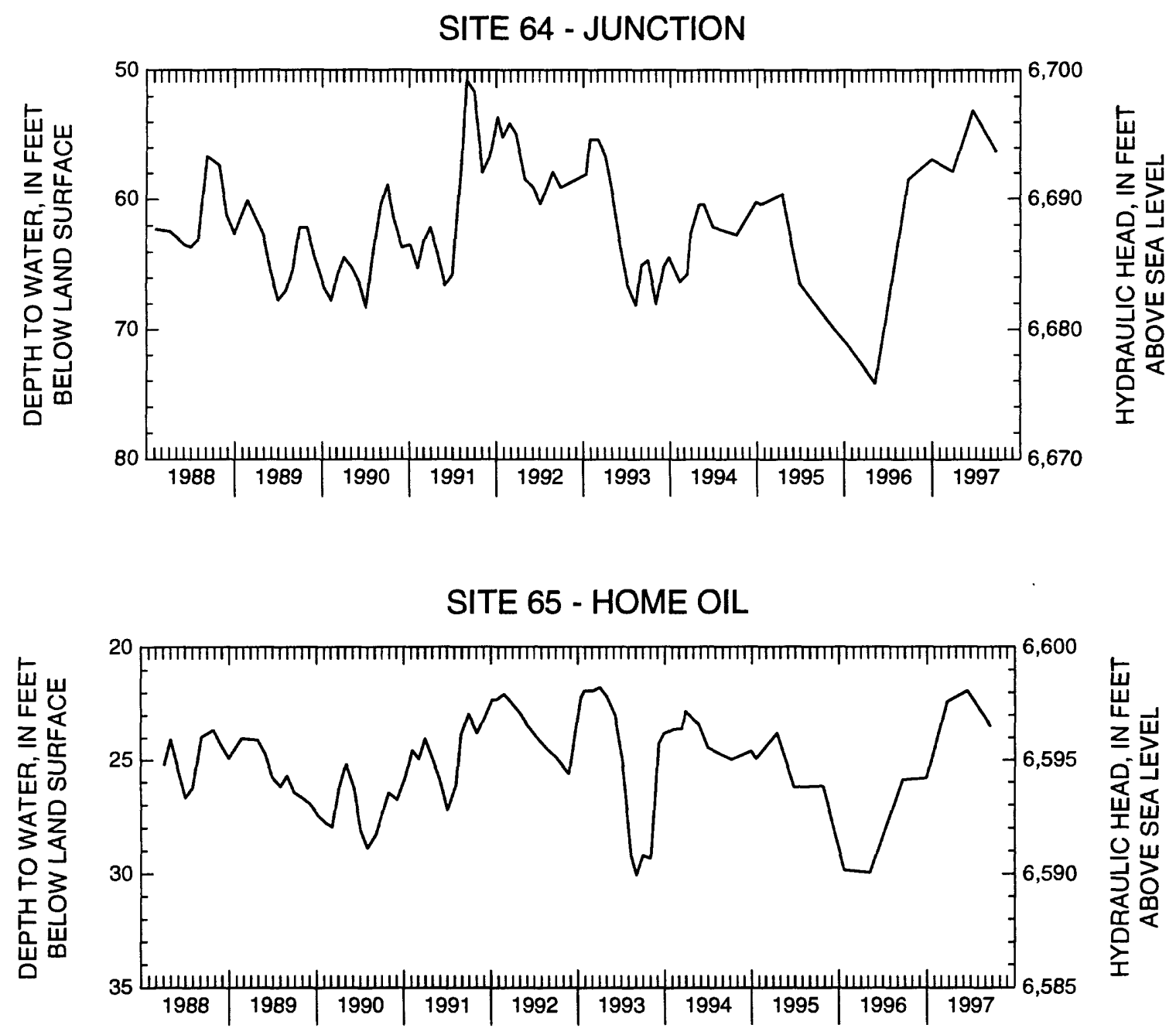

\section{SITE 66 - GRANITE HILL}

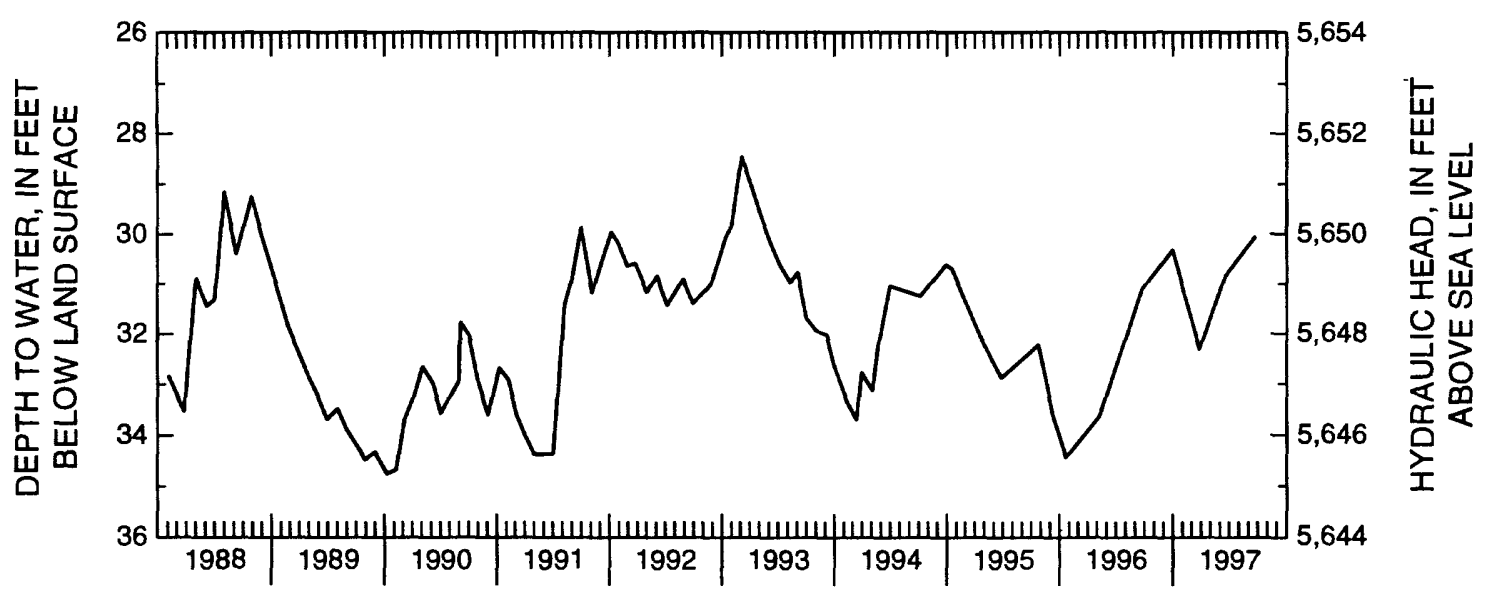

Figure 4.--Water-level data for selected wells and piezometers in the Albuquerque Basin--Continued. 


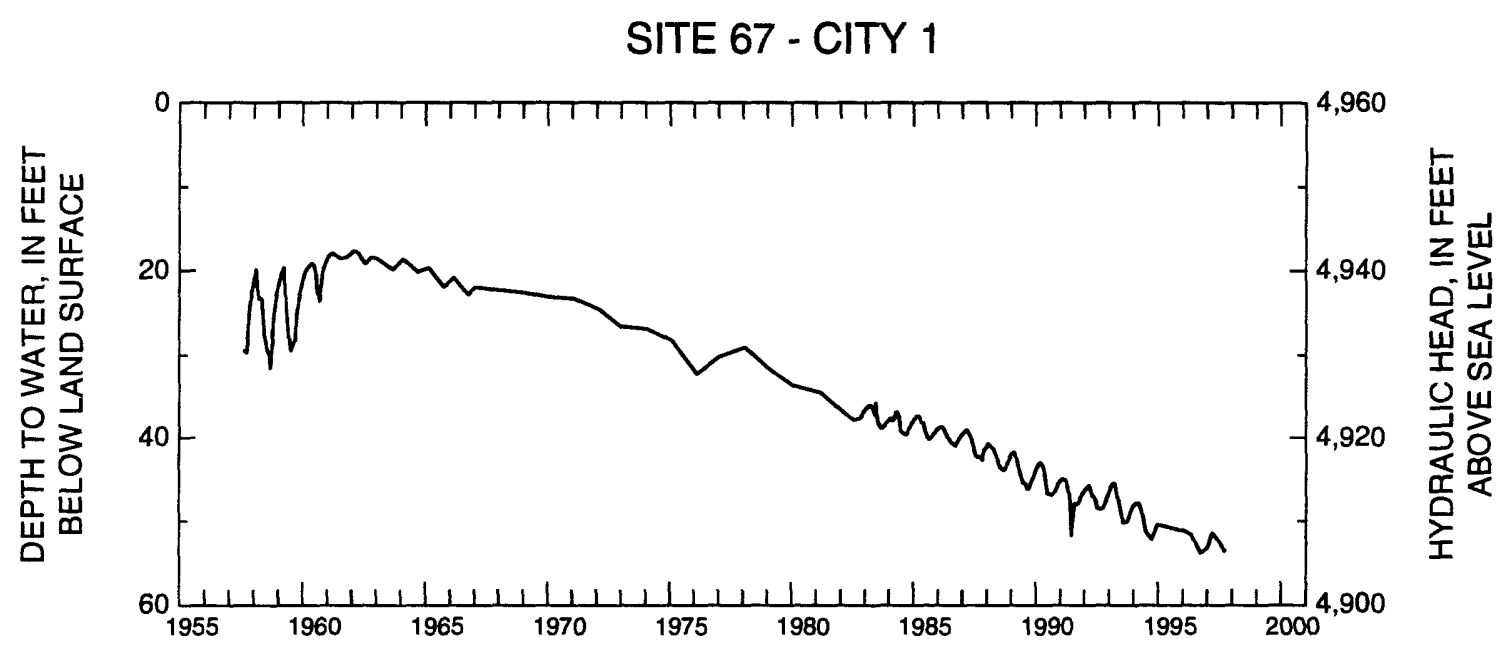

SITE 68 - CITY 2

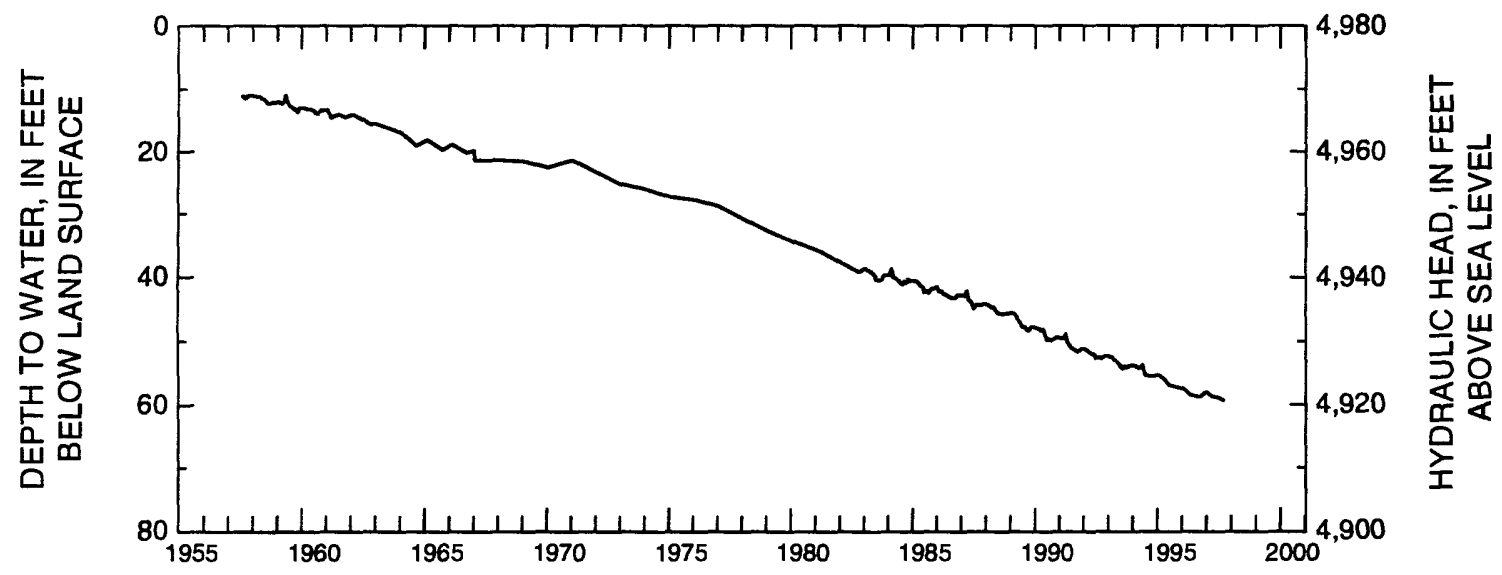

SITE 69 - CITY 3

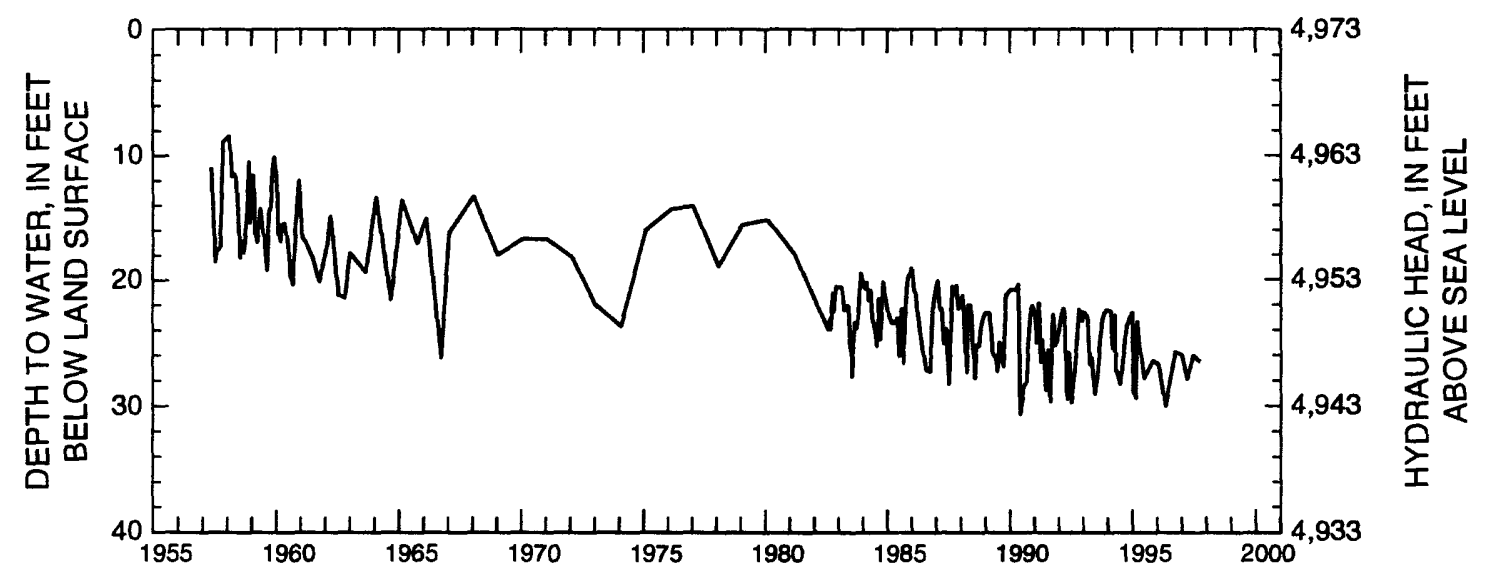

Figure 4.--Water-level data for selected wells and piezometers in the Albuquerque Basin--Continued. 


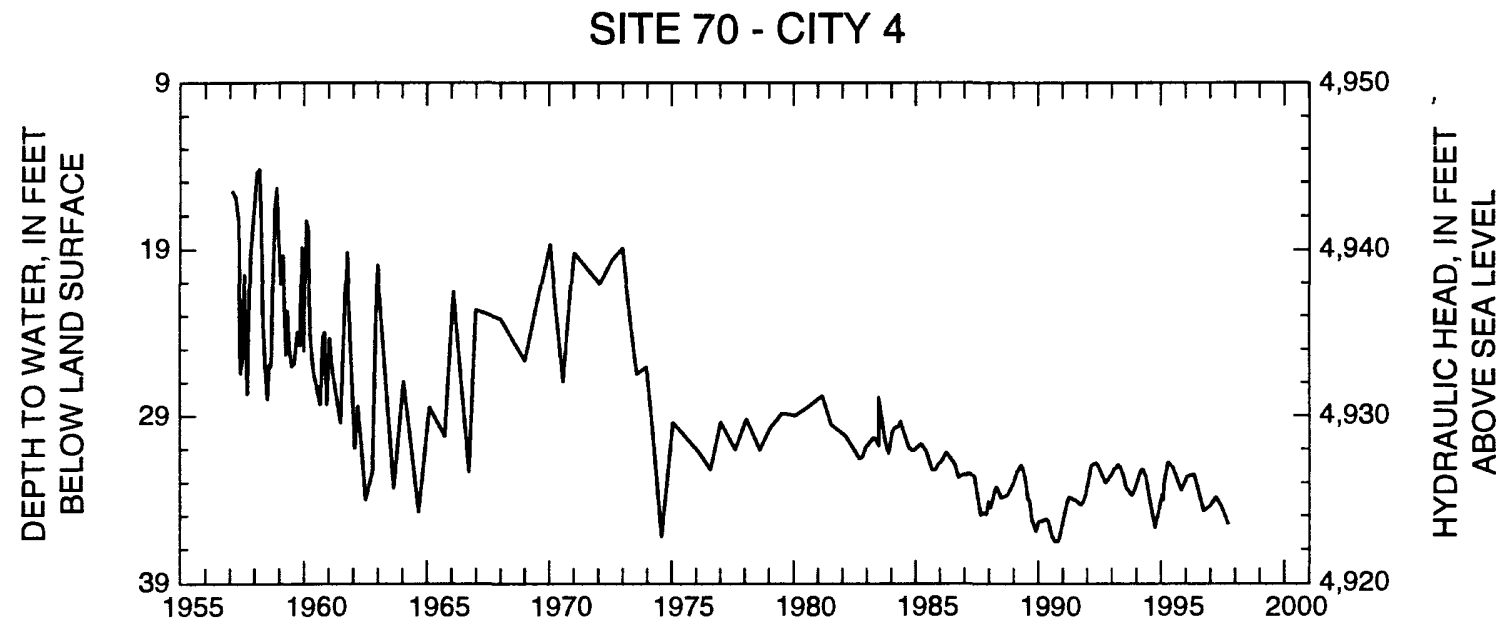

SITE 71 - CHAVA

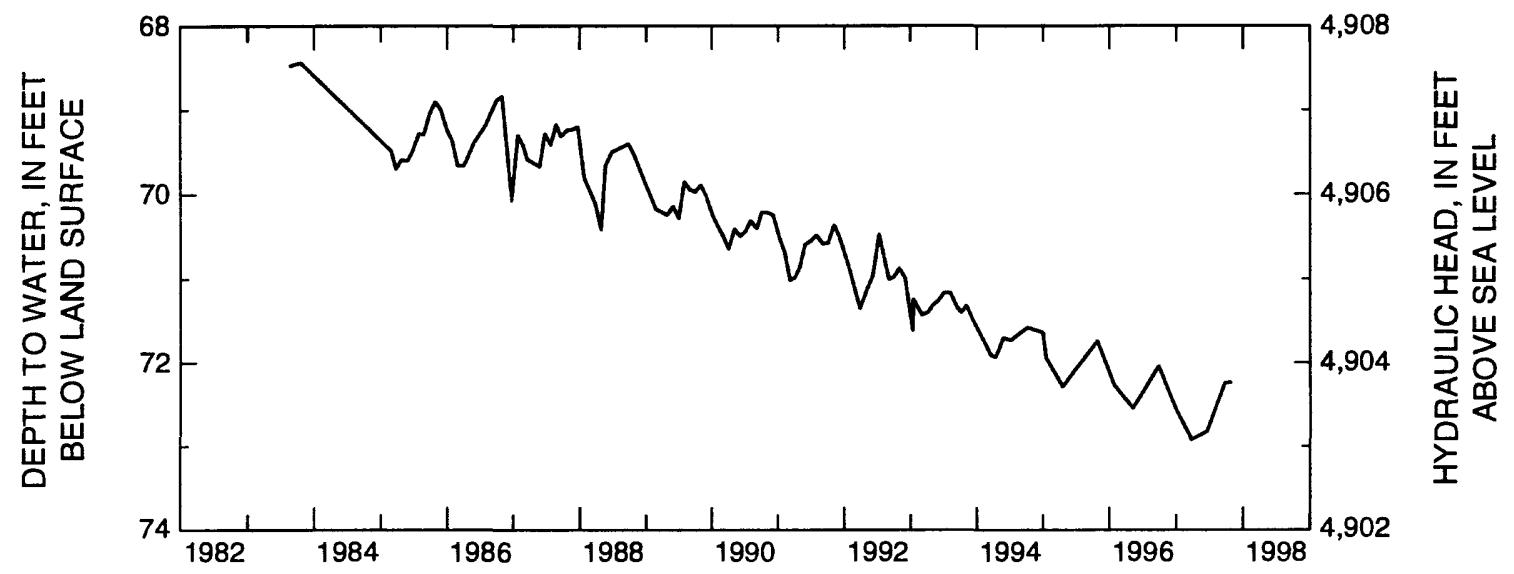

SITE 72 - RIO PUERCO TRADING POST

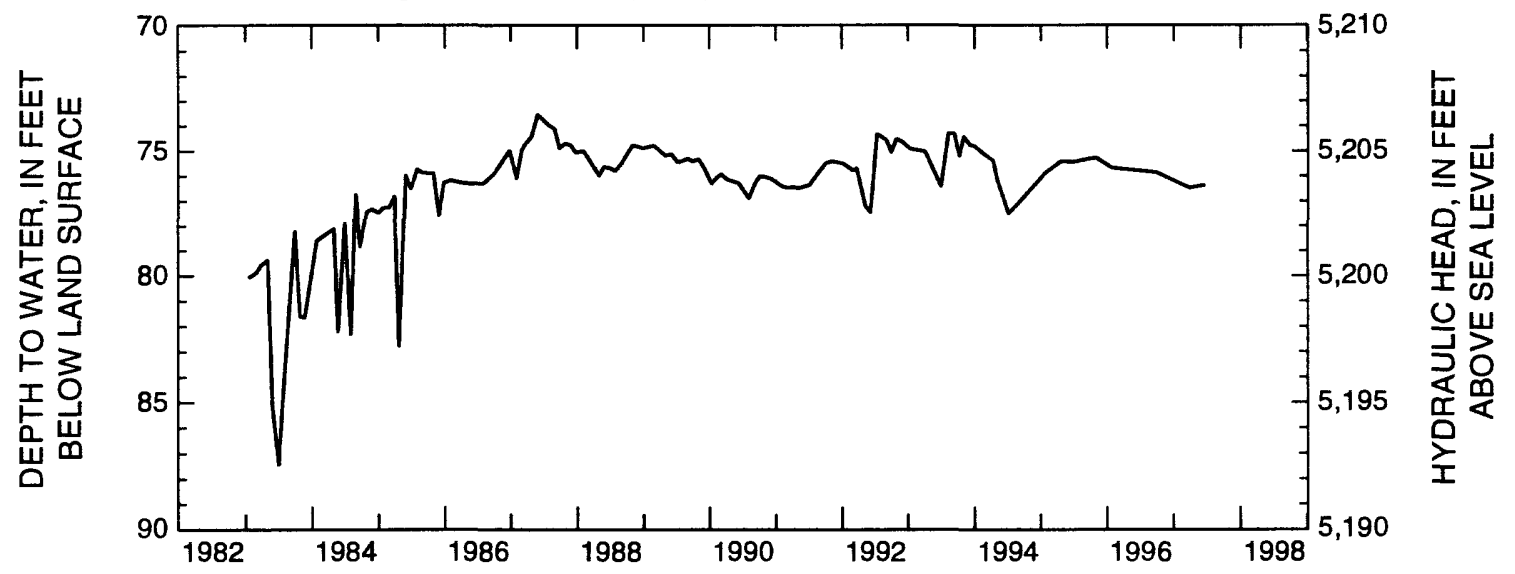

Figure 4.--Water-level data for selected wells and piezometers in the Albuquerque Basin--Continued. 
SITE 73 - CAÑNONCITO PUEBLO

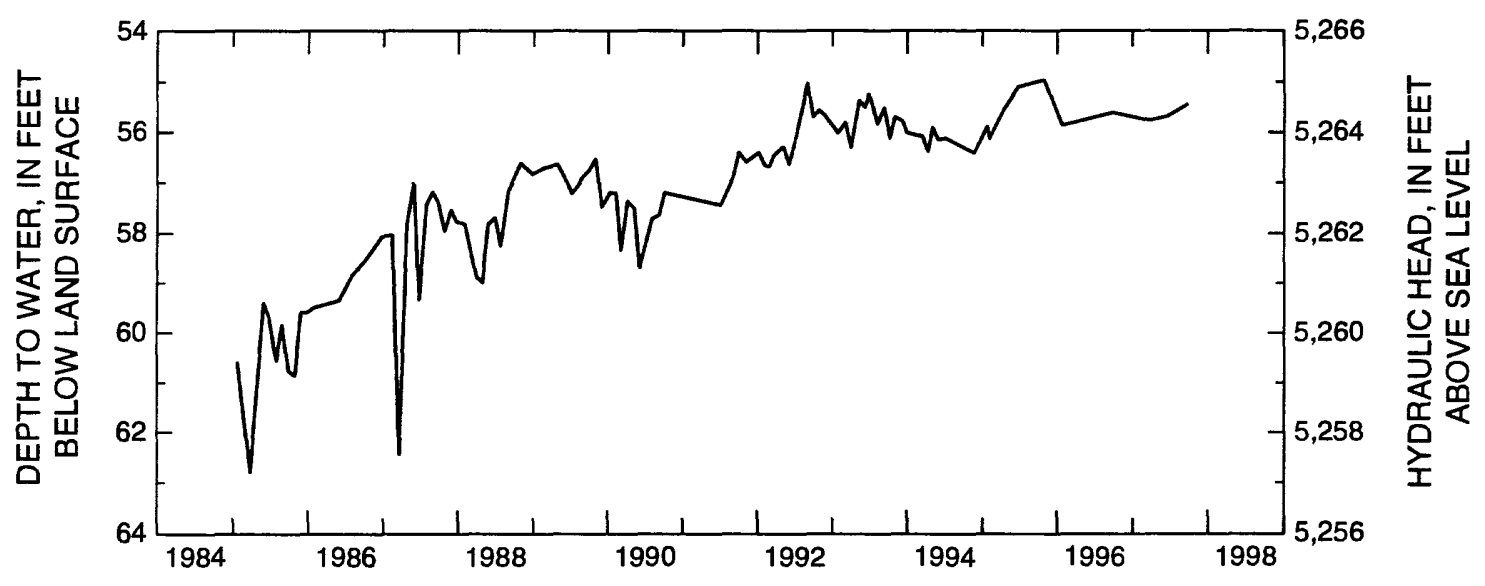

SITE 74 - BIA

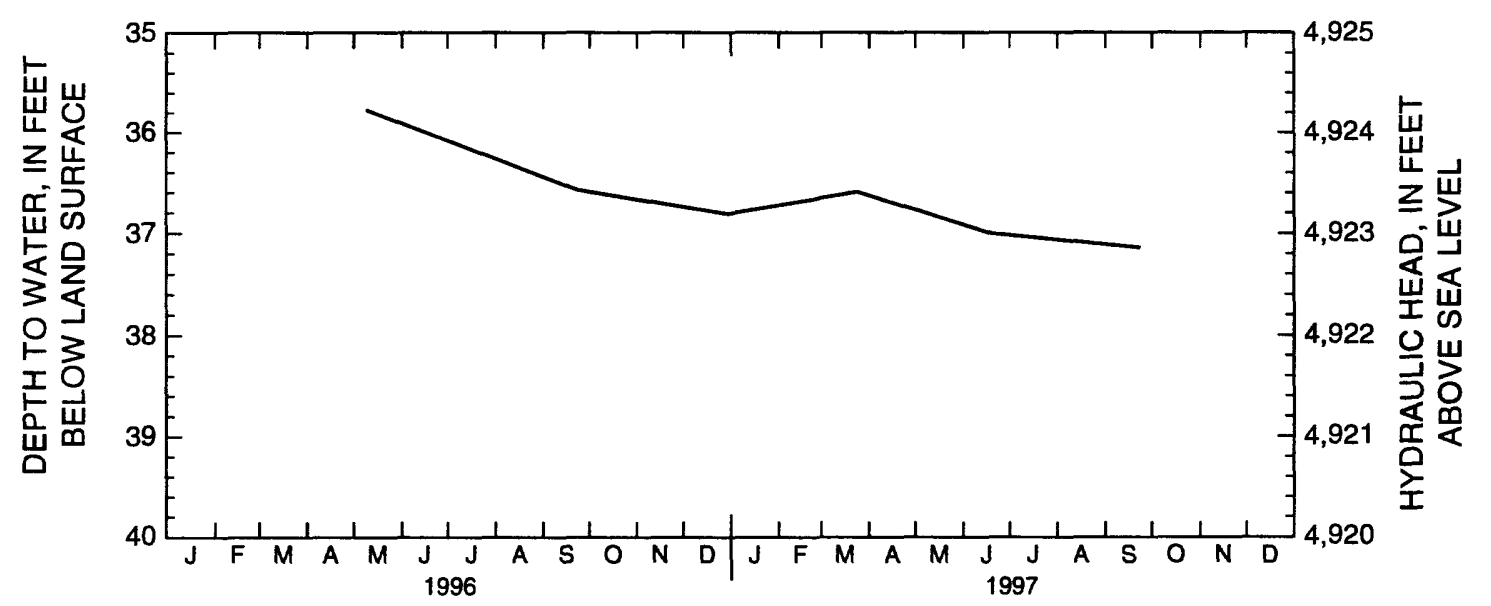

SITE 75 - TIERRA MIRAGE

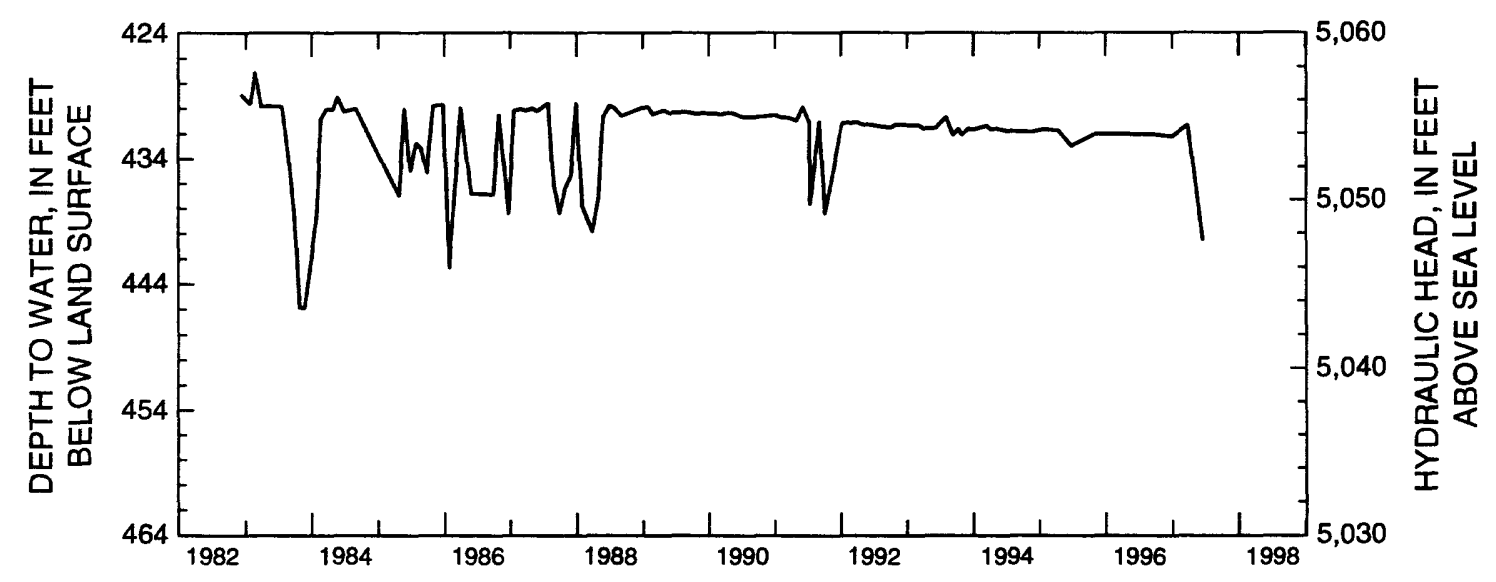

Figure 4.--Water-level data for selected wells and piezometers in the Albuquerque Basin--Continued. 
SITE 76 - SANTA ANA 1

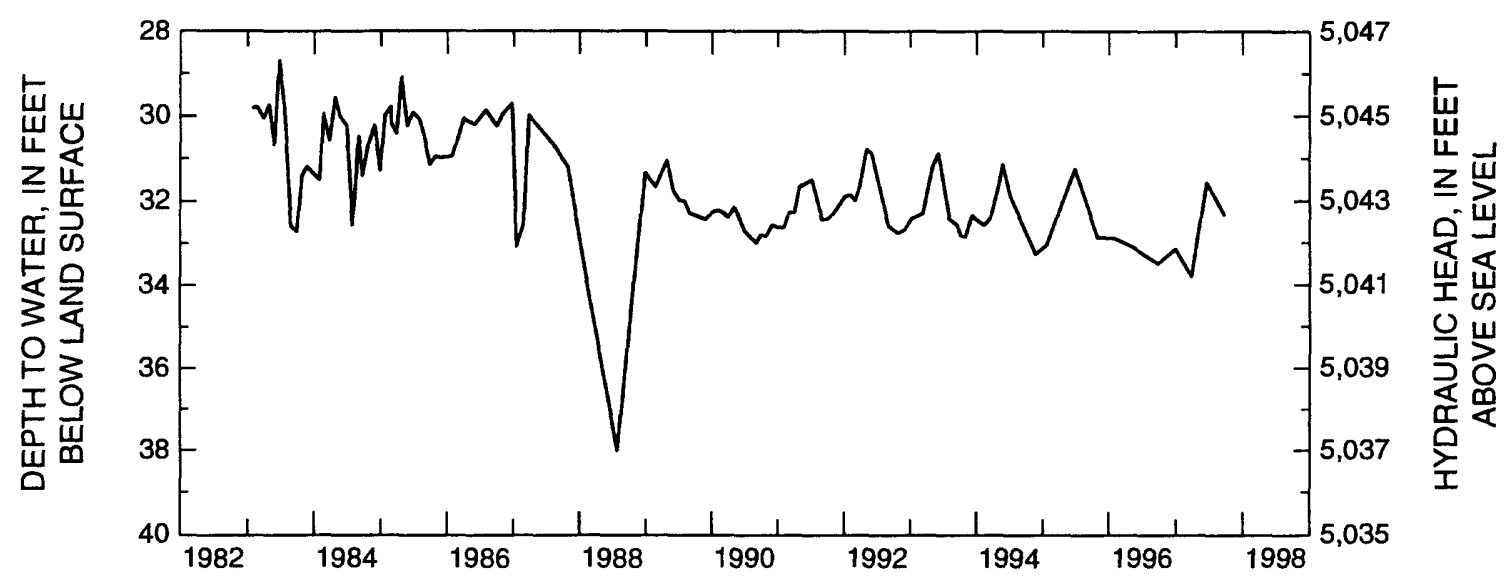

SITE 77 - SANTA ANA 2

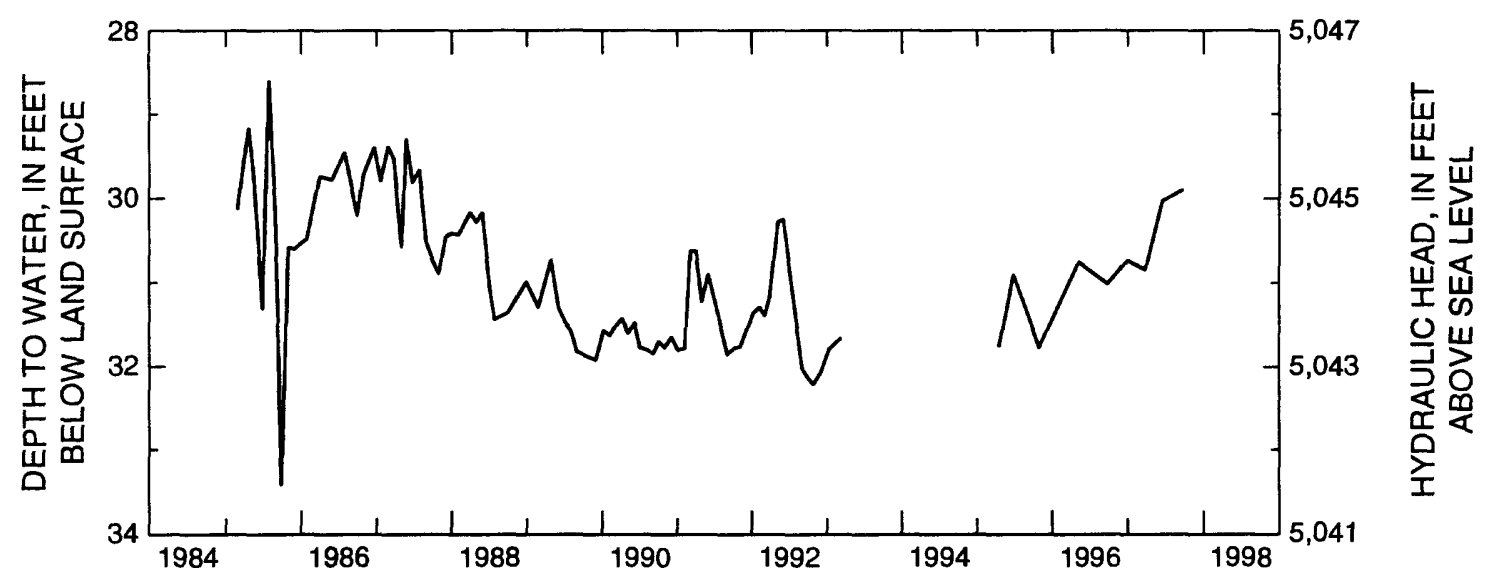

SITE 78 - SAN MIGUEL

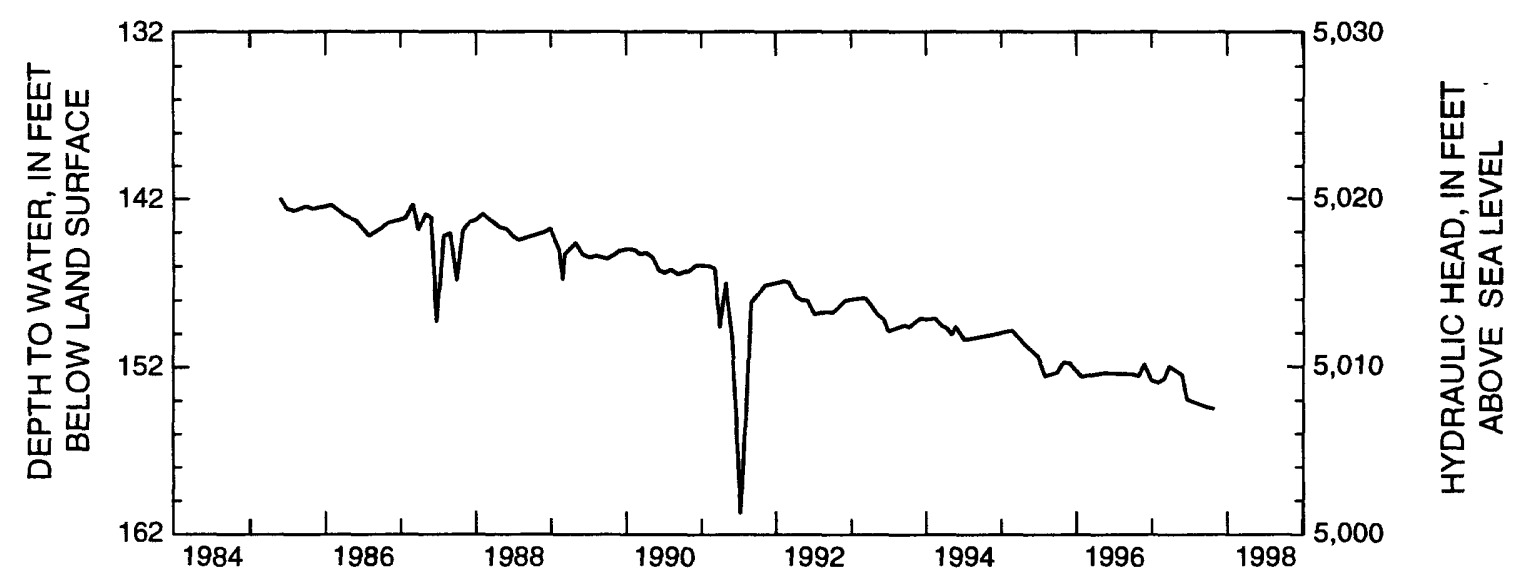

Figure 4.--Water-level data for selected wells and piezometers in the Albuquerque Basin--Continued. 


\section{SITE 79 - NELSON}

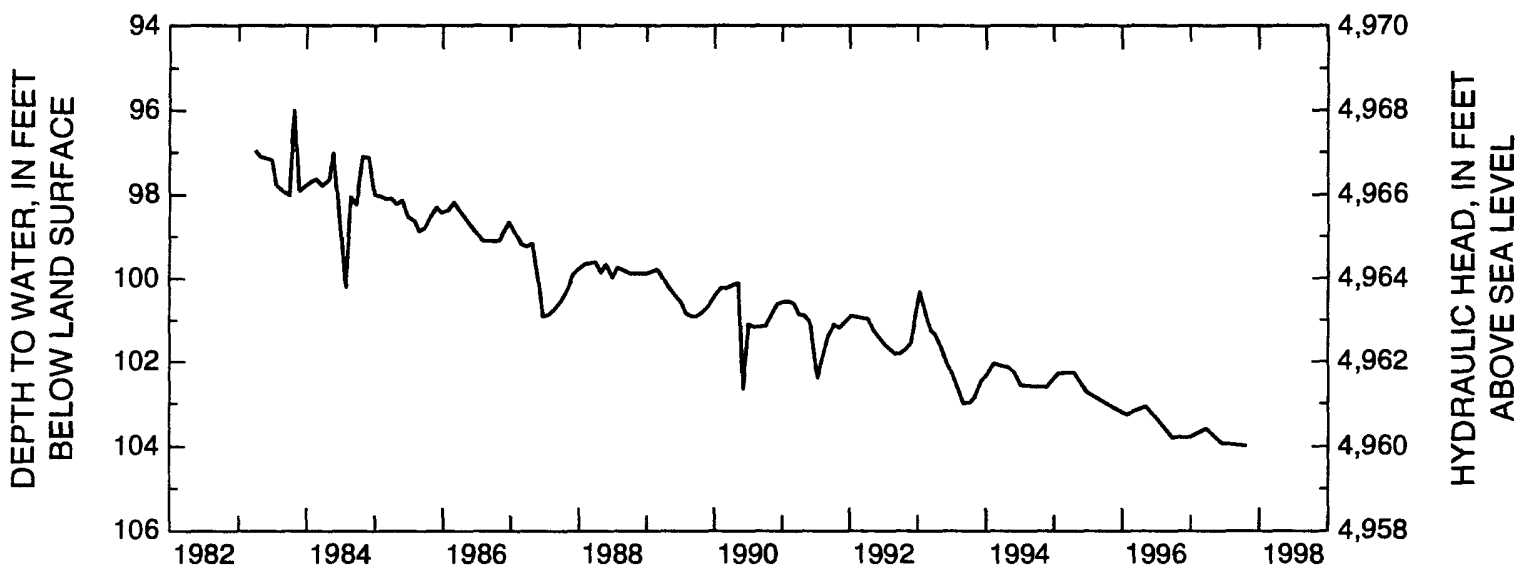

SITE 80 - LA LUZ DEL SOL

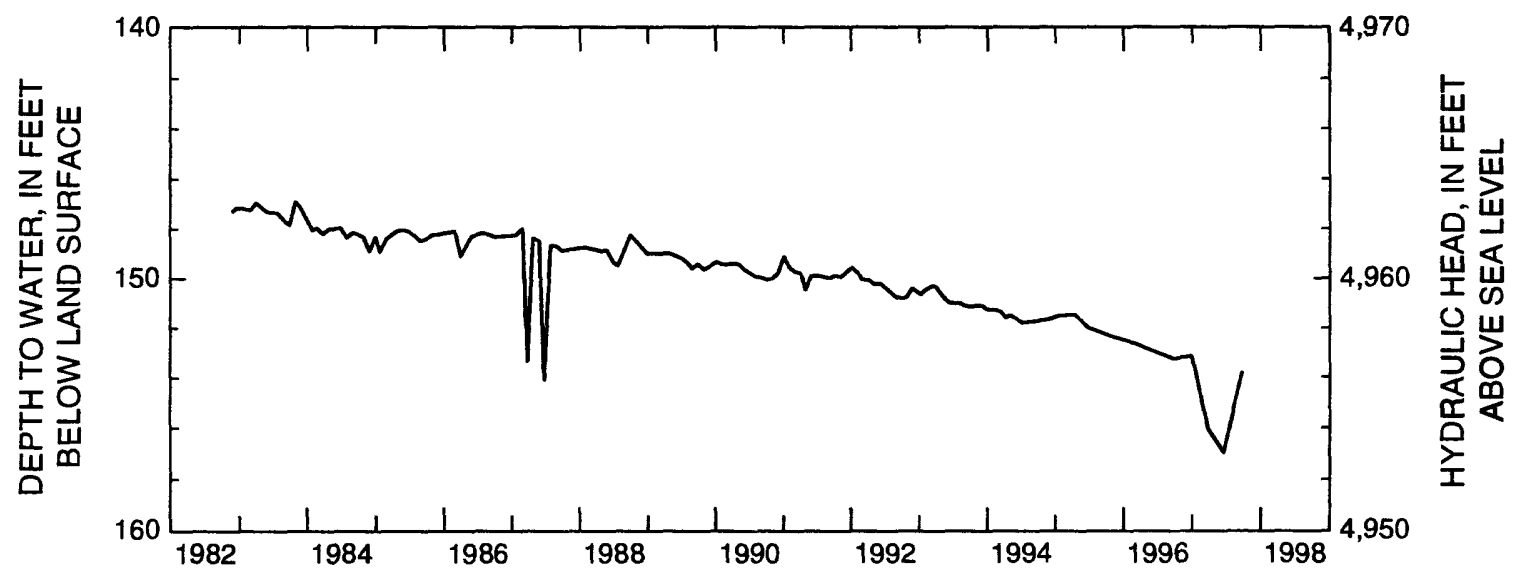

SITE 81 - SHOEMAKER

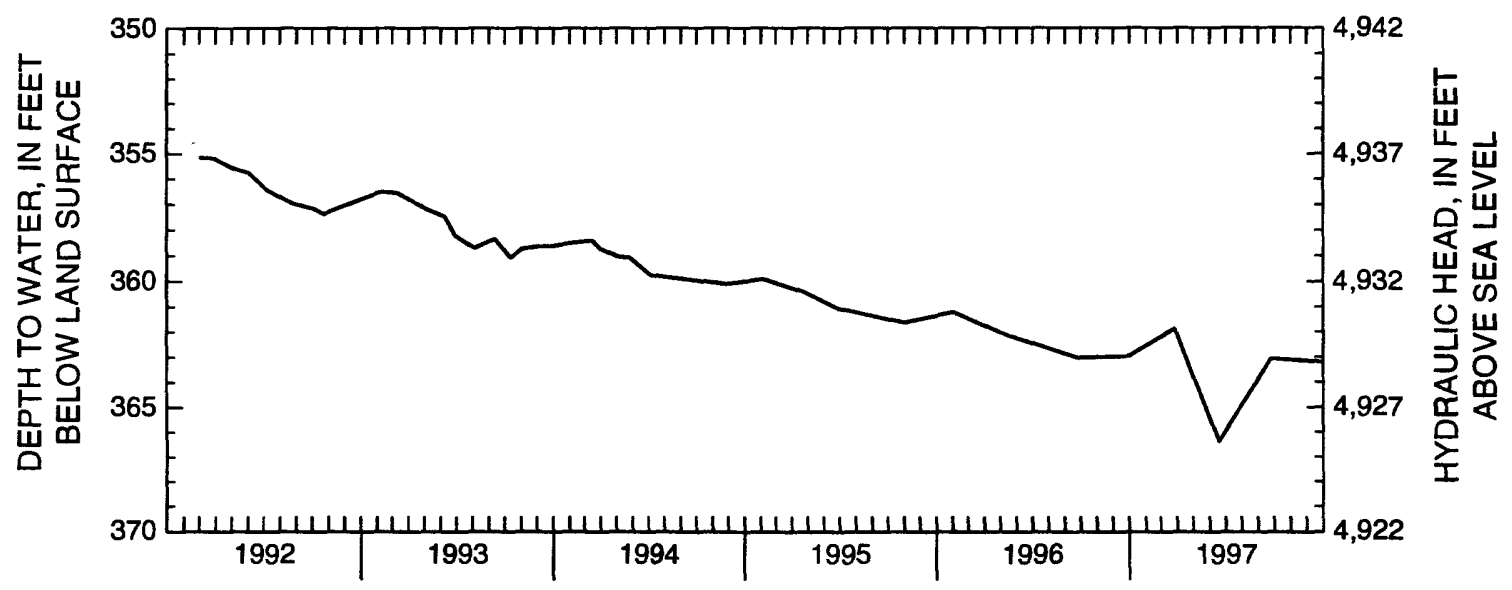

Figure 4.--Water-level data for selected wells and piezometers in the Albuquerque Basin--Continued. 


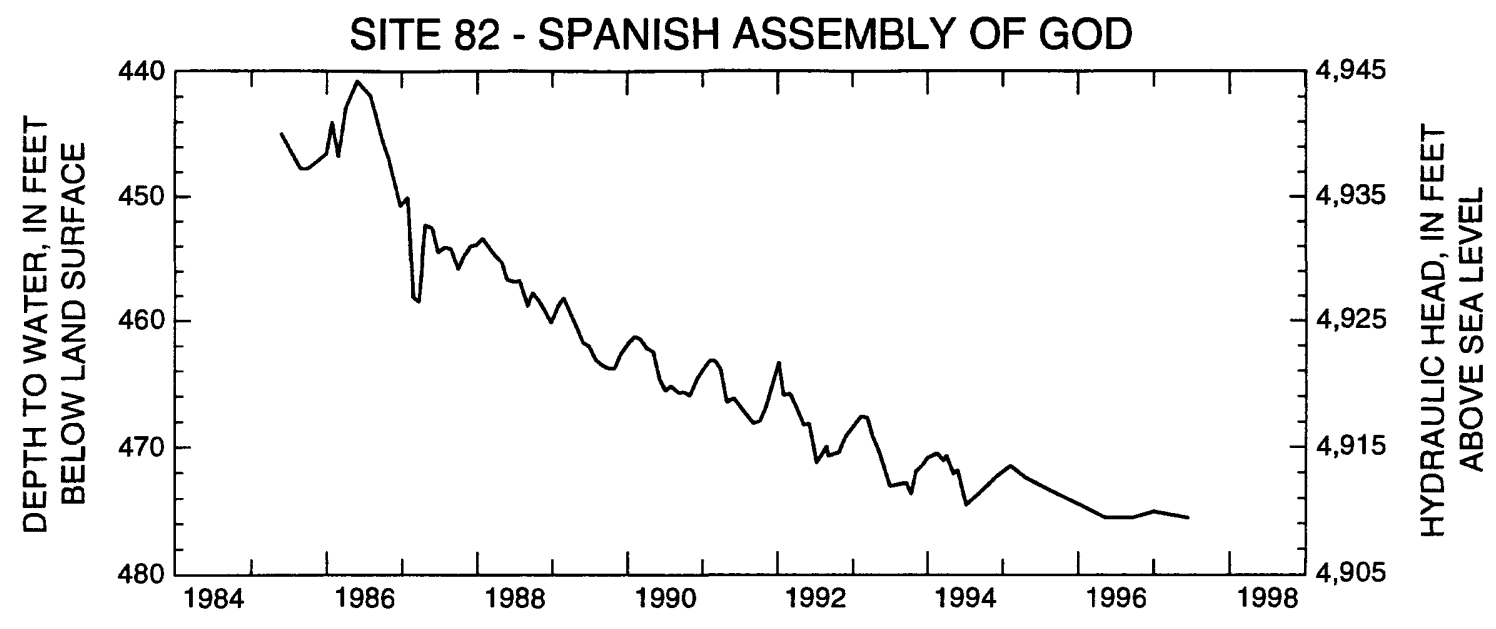

SITE 83 - FOUR HILLS
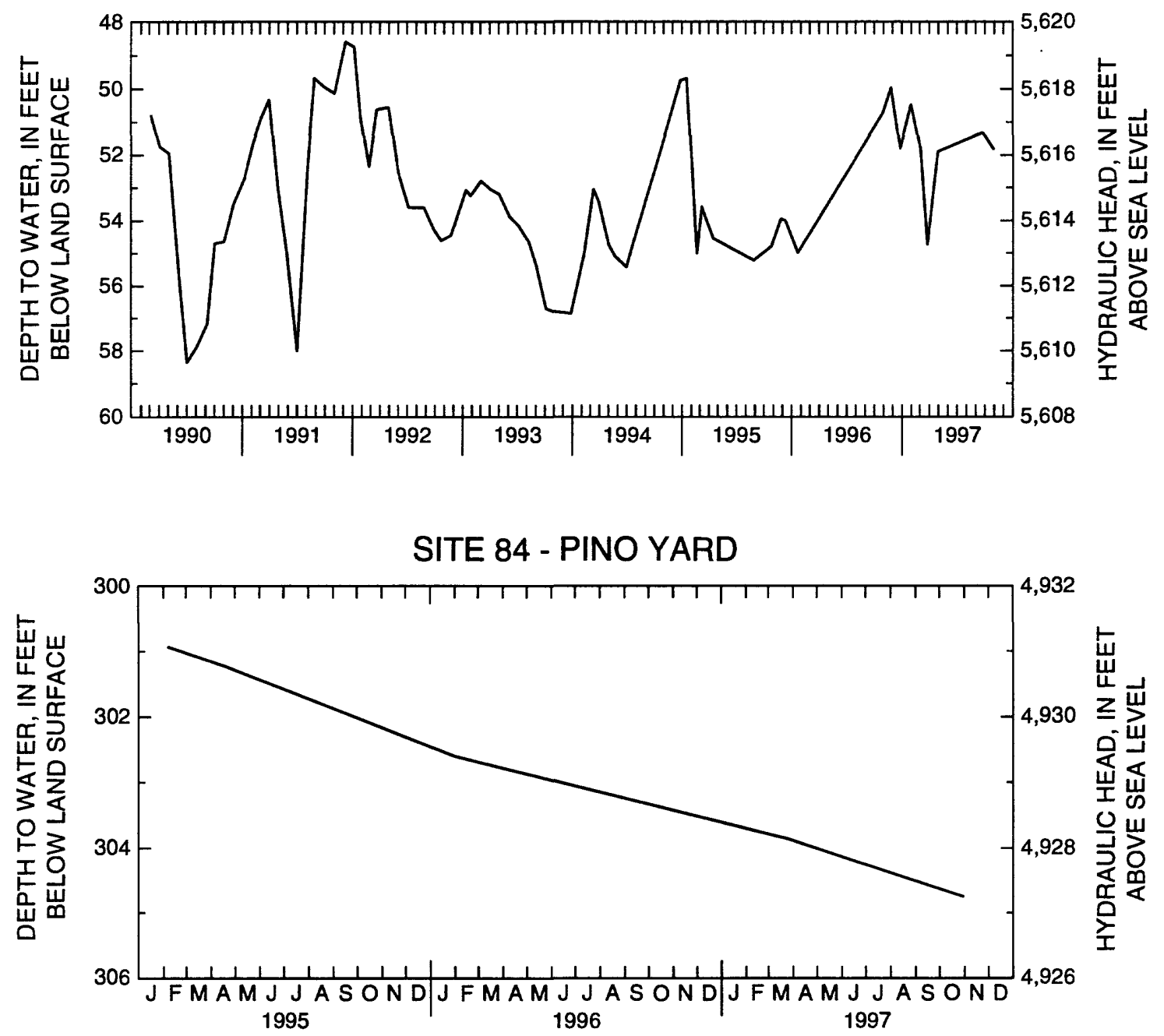

Figure 4.--Water-level data for selected wells and piezometers in the Albuquerque Basin--Continued. 


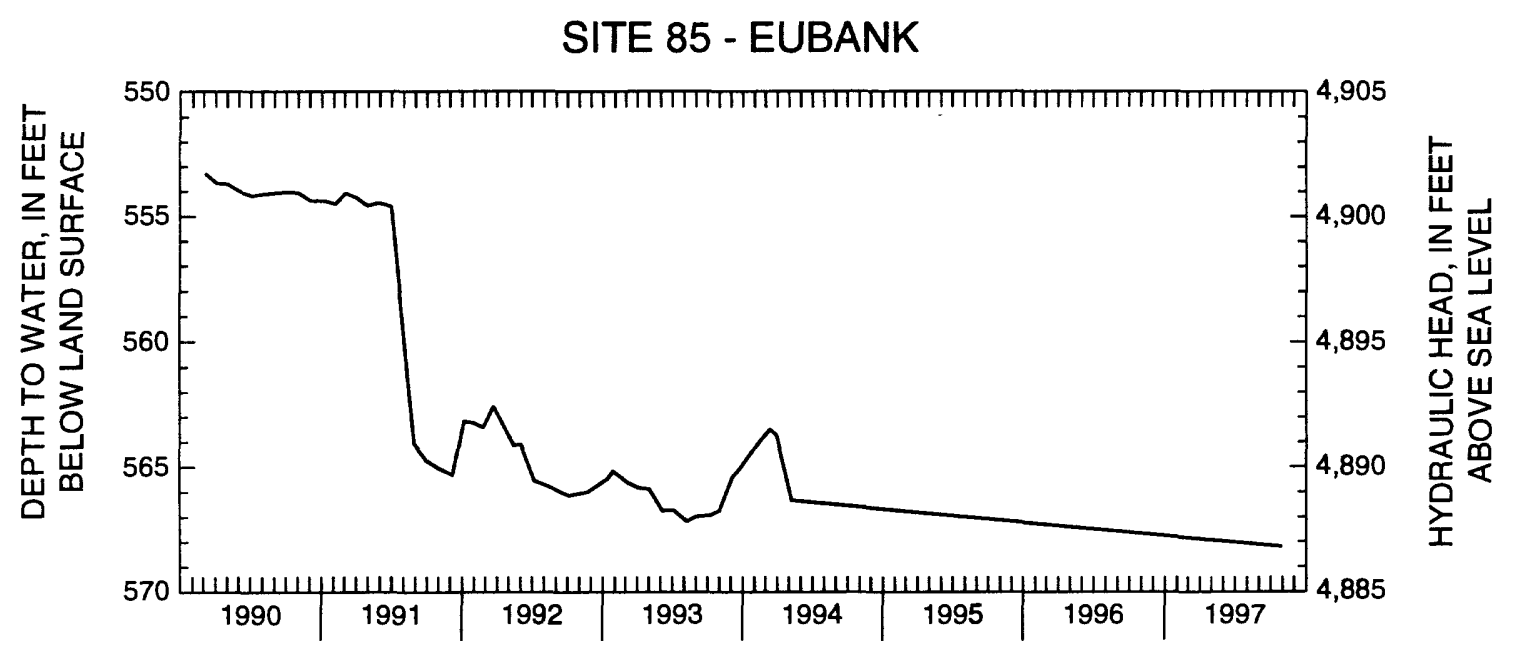

Figure 4.--Water-level data for selected wells and piezometers in the Albuquerque Basin--Concluded.

\section{REFERENCES CITED}

Anderholm, S.K., and Bullard, T.F., 1987, Description of piezometer nests and water levels in the Rio Grande Valley near Albuquerque, Bernalillo County, New Mexico: U.S. Geological Survey Open-File Report 87$122,51 \mathrm{p}$.

Kues, G.E., 1987, Ground-water-level data for the Albuquerque-Belen Basin, New Mexico, through water year 1985: U.S. Geological Survey Open-File Report 87-116, $51 \mathrm{p}$.

Rankin, D.R., 1994, Water-level data for the Albuquerque Basin, New Mexico, October 1, 1986, through September 30, 1990: U.S. Geological Survey Open-File Report 94-349, 29 p.

1996, Water-level data for the Albuquerque Basin, New Mexico, period of record through September 30, 1995: U.S. Geological Survey Open-File Report 96664A, $28 \mathrm{p}$.

Thorn, C.R., McAda, D.P., and Kernodle, J.M., 1993, Geohydrologic framework and hydrologic conditions in the Albuquerque Basin, central New Mexico: U.S. Geological Survey Water-Resources Investigations Report 93-4149, 106 p.
U.S. Bureau of the Census, 1980: Master area reference file for 1980 census.

1991: Master area reference file for 1991 census.

U.S. Department of Commerce, 1991, 1990 census of population and housing, Summary population and housing characteristics, New Mexico: 1990 CPH-1-33, variously paged.

Wilkins, D.W., 1986, Characteristics and properties of the basin-fill aquifer determined from three test wells west of Albuquerque, Bernalillo County, New Mexico: U.S. Geological Survey Water-Resources Investigations Report 86-4187, 78 p. 